\title{
\#USGS
}

Prepared in cooperation with the City of Rapid City

\section{Water-Quality Characteristics of Stormwater Runoff in Rapid City, South Dakota, 2008-14}

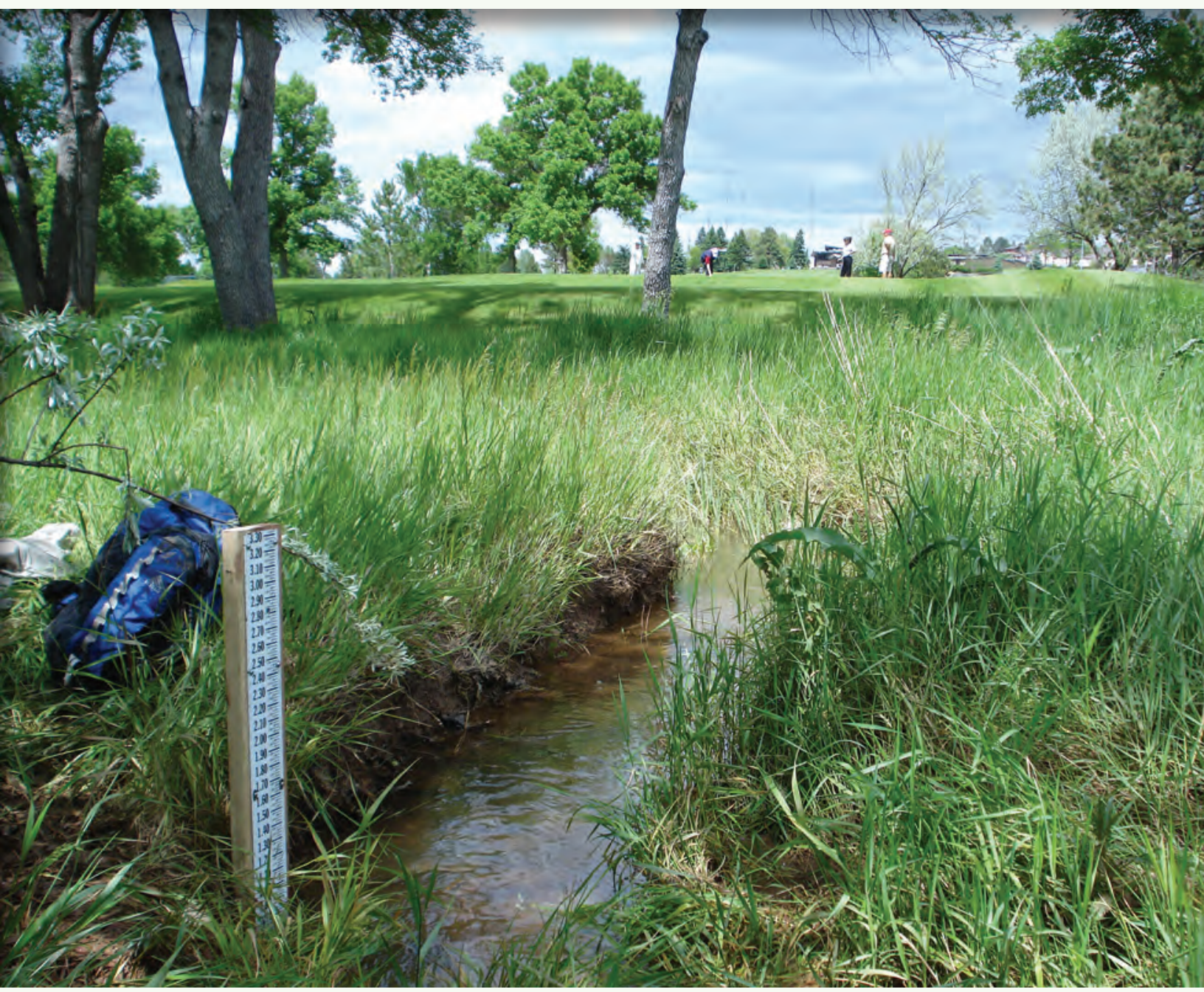

Scientific Investigations Report 2015-5069

U.S. Department of the Interior U.S. Geological Survey 
Cover. Right: Stage plate at Arrowhead drainage basin monitoring site upstream from Arrowhead Country Club.

Photograph by John Stamm, U.S. Geological Survey (USGS).

Left (top to bottom):

Automated sampler bottles containing stormwater runoff from the Arrowhead drainage basin being processed in the laboratory. Photograph by Galen Hoogestraat, USGS.

Stormwater runoff following a May 2008 storm event in the Arrowhead drainage basin. Photograph by John Stamm, USGS.

Stormwater runoff in the Arrowhead drainage basin immediately below Arrowhead Country Club during a May 2010 storm event. Photograph by Galen Hoogestraat, USGS.

U.S. Geological Survey hydrologic technicians measuring discharge during a May 2012 stormwater runoff event at the Meade-Hawthorne drainage basin monitoring site. Photograph by Galen Hoogestraat, USGS. 


\section{Water-Quality Characteristics of Stormwater Runoff in Rapid City, South Dakota, 2008-14}

By Galen K. Hoogestraat

Prepared in cooperation with the City of Rapid City

Scientific Investigations Report 2015-5069 


\title{
U.S. Department of the Interior SALLY JEWELL, Secretary
}

\section{U.S. Geological Survey \\ Suzette M. Kimball, Acting Director}

\author{
U.S. Geological Survey, Reston, Virginia: 2015
}

For more information on the USGS - the Federal source for science about the Earth, its natural and living resources, natural hazards, and the environment—visit http://www.usgs.gov or call 1-888-ASK-USGS.

For an overview of USGS information products, including maps, imagery, and publications, visit http://www.usgs.gov/pubprod/.

Any use of trade, firm, or product names is for descriptive purposes only and does not imply endorsement by the U.S. Government.

Although this information product, for the most part, is in the public domain, it also may contain copyrighted materials as noted in the text. Permission to reproduce copyrighted items must be secured from the copyright owner.

Suggested citation:

Hoogestraat, G.K., 2015, Water-quality characteristics of stormwater runoff in Rapid City, South Dakota, 2008-14:

U.S. Geological Survey Scientific Investigations Report 2015-5069, 27 p., http://dx.doi.org/10.3133/sir20155069.

ISSN 2328-0328 (online) 


\section{Acknowledgments}

The author would like to acknowledge all of the professionals, university students, and staff who have contributed directly or indirectly to stormwater research in Rapid City, South Dakota. These include Mary Bosworth from the City of Rapid City, John Stamm and Kevin Baker from the U.S. Geological Survey, and Dr. Scott Kenner and former graduate students Emily Fisher, Robert Prann, and Ryan Truax from the South Dakota School of Mines and Technology. 


\section{Contents}

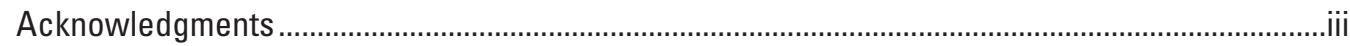

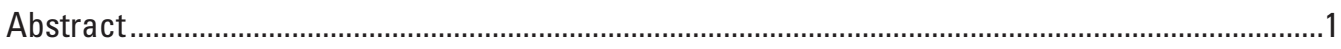

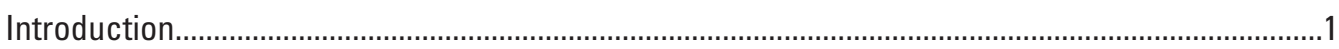

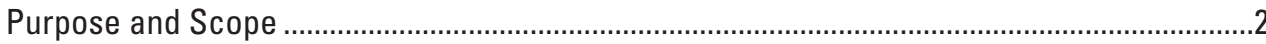

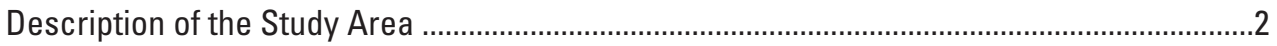

Arrowhead Drainage Basin ...............................................................................................2

Meade-Hawthorne Drainage Basin .....................................................................................4

Downtown Drainage Basin ..........................................................................................4

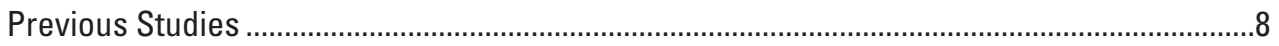

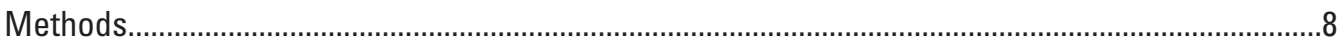

Stage, Discharge, and Precipitation Measurements .........................................................11

Collection, Processing, and Analysis of Water Samples ........................................................11

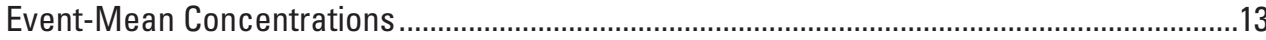

Quality Assurance and Quality Control ............................................................................. 14

Water-Quality Characteristics of Stormwater ............................................................................14

Arrowhead and Meade-Hawthorne Drainage Basins ..........................................................14

Downtown Drainage Basin .....................................................................................................16

Stormwater Pollutant Reductions .................................................................................21

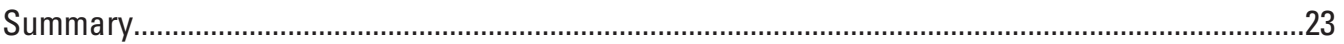

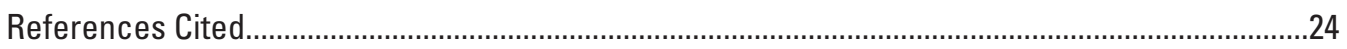

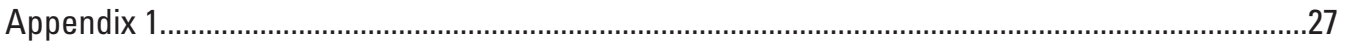




\section{Figures}

1. Map showing location of U.S. Geological Survey streamgages, stormwater monitoring sites, and drainage areas, Rapid City, South Dakota .......................................

2. Aerial imagery map showing monitoring sites in the Arrowhead drainage basin ............5

3. Aerial imagery map showing the monitoring site in the Meade-Hawthorne drainage basin......

4. Aerial imagery map showing the wetland channels and monitoring sites for the 1st, 2nd, and 3rd Street outfalls in the Downtown drainage basin, Rapid City, South

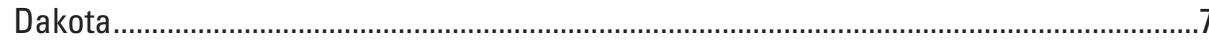

5. Schematic and photograph of flow divider structure located at the 3rd Street outfall of the Downtown drainage basin.

6. Profile schematic and photos of the 3rd Street wetland channel during dry weather conditions.

7. Schematic showing automated sampler at Arrowhead and Meade-Hawthorne drainage basin monitoring sites

8. Boxplots of event-mean concentrations for the Arrowhead and Meade-Hawthorne drainage basins, 2008-12

9. Graphs showing relations between event-mean concentrations in the Arrowhead and Meade-Hawthorne drainage basins, 2008-12

10. Boxplots of water-quality concentrations at Downtown drainage basin sites, 2013-14

11. Graphs showing inflow and outflow data for 3rd Street wetland channel in the Downtown drainage basin during runoff event on September 23, 2013.

12. Plot showing relation between wetland total volume and pollutant reductions for total suspended solids, ammonia, phosphorus, and fecal coliform bacteria for the wetland channels in the Downtown drainage basin, 2013-14.

\section{Tables}

1. List of monitoring sites in the Arrowhead, Meade-Hawthorne, and Downtown drainage basins, Rapid City, South Dakota..

2. Select design information for three wetland channels located at the 1st, 2nd, and 3rd Street outfalls of the Downtown drainage basin.

3. Water-quality constituents measured in stormwater samples, and relevant standards or limits for Rapid Creek at Rapid City, South Dakota.

4. Event-mean concentrations of total suspended solids, fecal coliform bacteria, and Escherichia colifor the Arrowhead and Meade-Hawthorne drainage basins, 2008-12

5. Statistical summary of event-mean concentrations for total suspended solids, fecal coliform, and Escherichia coli for the Arrowhead and Meade-Hawthorne drainage basins, 2008-12

6. Summary of wetland water-quality concentrations at Downtown drainage basin monitoring sites, 2013-14

7. Mean pollutant reductions, in percent, for the 1st, 2nd, and 3rd Street wetland channels in the Downtown drainage basin, 2013-14 


\section{Conversion Factors}

Inch/Pound to International System of Units

\begin{tabular}{lll}
\hline \multicolumn{1}{c}{ Multiply } & By & \multicolumn{1}{c}{ To obtain } \\
\hline inch (in.) & Length & \\
foot (ft) & 2.54 & centimeter $(\mathrm{cm})$ \\
mile (mi) & 0.3048 & meter $(\mathrm{m})$ \\
\hline & 1.609 & kilometer $(\mathrm{km})$ \\
\hline square mile $\left(\mathrm{mi}^{2}\right)$ & Area & \\
\hline & 2.590 & square kilometer $\left(\mathrm{km}^{2}\right)$ \\
\hline cubic foot $\left(\mathrm{ft}^{3}\right)$ & Volume & cubic meter $\left(\mathrm{m}^{3}\right)$ \\
\hline & 0.02832 & \\
\hline cubic foot per second $\left(\mathrm{ft}^{3} / \mathrm{s}\right)$ & Flow rate & cubic meter $\mathrm{per} \mathrm{second}\left(\mathrm{m}^{3} / \mathrm{s}\right)$ \\
\hline
\end{tabular}

\section{Datum}

Horizontal coordinate information is referenced to the North American Datum of 1983 (NAD 83).

\section{Supplemental Information}

Specific conductance is given in microsiemens per centimeter at 25 degrees Celsius $(\mu \mathrm{S} / \mathrm{cm}$ at $\left.25^{\circ} \mathrm{C}\right)$.

Concentrations of chemical constituents in water are given either in milligrams per liter (mg/L) or micrograms per liter $(\mu \mathrm{g} / \mathrm{L})$. Concentrations of bacteria are given in colony forming units per 100 milliliters (cfu/100 mL) or most probable number per 100 milliliters (mpn/100 mL).

\section{Abbreviations}

$\begin{array}{ll}< & \text { less than } \\ \text { BMP } & \text { best-management practice } \\ \text { E. coli } & \text { Escherichia coli } \\ \text { EMC } & \text { event-mean concentration } \\ \text { HDPE } & \text { high-density polyethylene } \\ \text { MRL } & \text { minimum reporting level } \\ R^{2} & \text { coefficient of determination } \\ { }^{2} & \text { registered trademark } \\ \text { TMDL } & \text { total maximum daily load } \\ \text { TSS } & \text { total suspended solids } \\ \text { USGS } & \text { U.S. Geological Survey }\end{array}$




\title{
Water-Quality Characteristics of Stormwater Runoff in Rapid City, South Dakota, 2008-14
}

\author{
By Galen K. Hoogestraat
}

\section{Abstract}

The water quality of Rapid Creek is important because the reach that flows through Rapid City, South Dakota, is a valuable spawning area for a self-sustaining trout fishery, actively used for recreation, and a seasonal municipal water supply for the City of Rapid City. This report presents the current (2008-14) water-quality characteristics of urban stormwater runoff in selected drainage networks within the City of Rapid City, and provides an evaluation of the pollutant reductions of wetland channels implemented as a best-management practice. Stormwater runoff data were collected at nine sites in three drainage basins within Rapid City: the Arrowhead (2 monitoring sites), Meade-Hawthorne (1 monitoring site), and Downtown (6 monitoring sites) drainage basins. Stormwater runoff was evaluated for concentrations of total suspended solids (TSS) and bacteria at sites in the Arrowhead and Meade-Hawthorne drainage basins, and for concentrations of TSS, chloride, bacteria, nutrients, and metals at sites in the Downtown drainage basin.

For the Arrowhead and Meade-Hawthorne sites, eventmean concentrations typically exceeded the TSS and bacteria beneficial-use criteria for Rapid Creek by 1-2 orders of magnitude. Comparing the two drainage basins, median TSS event-mean concentrations were more than two times greater at the Meade-Hawthorne outlet (520 milligrams per liter) than the Arrowhead outlet (200 milligrams per liter). Median fecal coliform bacteria event-mean concentrations also were greater at the Meade-Hawthorne outlet site (30,000 colony forming units per 100 milliliters) than the Arrowhead outlet site (17,000 colony forming units per 100 milliliters). A comparison to relevant standards indicates that stormwater runoff from the Downtown drainage basin exceeded criteria for bacteria and TSS, but concentrations generally were below standards for nutrients and metals. Stormwater-quality conditions from the Downtown drainage basin outfalls were similar to or better than stormwater-quality conditions observed in the Arrowhead and Meade-Hawthorne drainage basins. Three wetland channels located at the outlet of the Downtown drainage basin were evaluated for their pollutant reduction capability. Mean reductions in TSS and lead concentrations were greater than 40 percent for all three wetland channels. Total nitrogen, phosphorus, copper, and zinc concentrations also were reduced by at least 20 percent at all three wetlands. Fecal coliform bacteria concentrations typically were reduced by about 21 and 36 percent at the 1 st and 2nd Street wetlands, respectively, but the reduction at the 3rd Street wetland channel was nearly zero percent. Total wetland storage volume affected pollutant reductions because TSS, phosphorus, and ammonia reductions were greatest in the wetland with the greatest volume. Chloride concentrations typically increased from inflow to outflow at the 2 nd and 3rd Street wetland channels.

\section{Introduction}

Storm runoff from urbanized lands is known to harm surface-water resources by increasing stream velocities, destroying natural habitat, and increasing pollutant loads in the receiving waters (for example, U.S. Environmental Protection Agency, 2003; Rasmussen and Schmidt, 2009). This uncontrolled discharge from affected lands can cause physical, biological, and chemical changes in the receiving waters, which impairs designated uses (U.S. Environmental Protection Agency, 2010). As runoff flows over the land or impervious surfaces (paved streets, parking lots, and building rooftops), the runoff accumulates debris, chemicals, sediment, or other pollutants that could adversely affect water quality if the runoff is discharged untreated. The water quality of Rapid Creek is important because the reach that flows through Rapid City, South Dakota, is a valuable spawning area for a self-sustaining trout fishery, actively used for recreation, and a seasonal municipal water supply for the City of Rapid City. The City of Rapid City is mandated by the U.S. Environmental Protection Agency to reduce the quantity of pollutants transported in urban runoff to the maximum extent possible. The associated regulations are described by Phase II of the National Pollutant Discharge Elimination System as applied to municipal separate storm sewer systems in small municipalities (populations of more than 50,000 and a density of at least 1,000 people per square mile). Water produced by municipal separate storm sewer systems must satisfy the water-quality requirements of the Clean Water Act (U.S. Environmental Protection Agency, 2010). 
In accordance with the Clean Water Act, the South Dakota Department of Environment and Natural Resources lists beneficial uses of major streams and rivers in the State. Rapid Creek within the city of Rapid City has beneficial uses of domestic water supply, coldwater permanent fish life propagation, immersion recreation, and limited-contact recreation (South Dakota Department of Environment and Natural Resources, 2010). The satisfaction of these beneficial uses are determined using numeric water-quality criteria, such as total suspended solids (TSS), fecal coliform and Escherichia coli (E. coli) bacteria, nutrients, and chloride. As of 2014, water quality in Rapid Creek for reaches upstream from Rapid City meets water-quality standards for designated beneficial uses; however, Rapid Creek from Canyon Lake to the Cheyenne River has poor water quality due to excessive fecal coliform and (or) E. coli bacteria levels (South Dakota Department of Environment and Natural Resources, 2014). A total maximum daily load (TMDL) for bacteria for the reaches within and downstream from Rapid City was approved by the South Dakota Department of Environment and Natural Resources in 2010. A TMDL is a calculation of the maximum amount of a pollutant that a waterbody can receive and still meet water-quality standards (South Dakota Department of Environment and Natural Resources, 2015). Approval of a TMDL for a waterbody commonly is followed by an implementation project with goals to reduce pollution sources within the drainage basin.

Control of sediment generated by construction sites and from urban land use within Rapid City is necessary for Rapid Creek to maintain a water-quality condition that satisfies its beneficial uses. The City of Rapid City encourages use of various best-management practices (BMPs), such as detention ponds, vegetated channels, and disconnected impervious area, for reducing the environmental effects of stormwater pollution. As part of its program, Rapid City has published the "Rapid City Stormwater Quality Manual" (City of Rapid City, 2009) on construction and post-construction control of stormwater discharges through BMPs. Within the "Rapid City Stormwater Quality Manual," various BMP devices are suggested and described in detail; however, little information exists on field-verified performance measures of these BMPs in Rapid City. Several BMP devices recently (after 2005) have been installed during site developments that include designs targeted at improving water quality. Such devices include extended sand-filter detention basins and constructed wetlands. To characterize the composition of stormwater runoff and to better understand the effects of BMPs on the quality of stormwater runoff, the U.S. Geological Survey (USGS) completed a study in cooperation with the City of Rapid City. The objectives of this study were to characterize the current (2008-14) composition of urban stormwater runoff in selected drainage networks within the City of Rapid City, and evaluate the pollutant reductions of wetland channels implemented as a BMP.

\section{Purpose and Scope}

The purpose of this report is to describe the water-quality characteristics of stormwater runoff from three drainage basins within the City of Rapid City during 2008-14 and compare those characteristics to relevant water-quality standards. Stormwater runoff data were collected in three drainage basins within Rapid City: the Arrowhead, Meade-Hawthorne, and Downtown drainage basins. Stormwater runoff was evaluated for concentrations of TSS and bacteria at sites in all three drainage basins, and for concentrations of TSS, chloride, bacteria, nutrients, and metals at sites in the Downtown drainage basin. Datasets from sites in the Downtown drainage basin were used to provide a comparison of inflow and outflow concentrations at stormwater treatment wetlands to assess the pollutant reduction capabilities of this BMP.

\section{Description of the Study Area}

Stormwater data were collected in three drainage basins within Rapid City: the Arrowhead (2 monitoring sites), Meade-Hawthorne (1 monitoring site), and Downtown drainage basins (6 monitoring sites; fig. 1, table 1). Rapid City is located on the eastern foothills of the Black Hills, which are susceptible to short-duration, intense, convective thunderstorm events during the spring and summer months (Driscoll and others, 2010). The mean annual (1981-2010) precipitation for Rapid City is 19.8 inches, of which 12.0 inches fall during April-July (National Oceanic and Atmospheric Administration, 2014). Rapid Creek originates in the western Black Hills area, and flows east through Rapid City to its mouth at the Cheyenne River. The mean annual flow for water years 1964-2014 for Rapid Creek at Rapid City (USGS streamgage $06414000)$ is 70.8 cubic feet per second $\left(\mathrm{ft}^{3} / \mathrm{s}\right)$ (U.S. Geological Survey, 2015).

\section{Arrowhead Drainage Basin}

The Arrowhead drainage basin (figs. 1-2) is located on the southwestern edge of Rapid City and drains approximately 5.8 square miles $\left(\mathrm{mi}^{2}\right)$ upon entering Rapid Creek. All drainage area values listed in this report were determined using geographical information system software, unless otherwise noted. The mean percentage of impervious area over the Arrowhead basin is 9.6 percent, as calculated using the National Land Cover Database (Fry and others, 2011). The predominant land use/land cover is agricultural/forest (57 percent) followed by low-density residential (27 percent) and park (6.4 percent) with less than 5 percent of medium-density residential, mobile home residential, public, general commercial, and floodway. The main conveyance channel is roughly 90 percent open vegetated channel, where plants can slow the stormwater runoff and use it by way of evapotranspiration. 


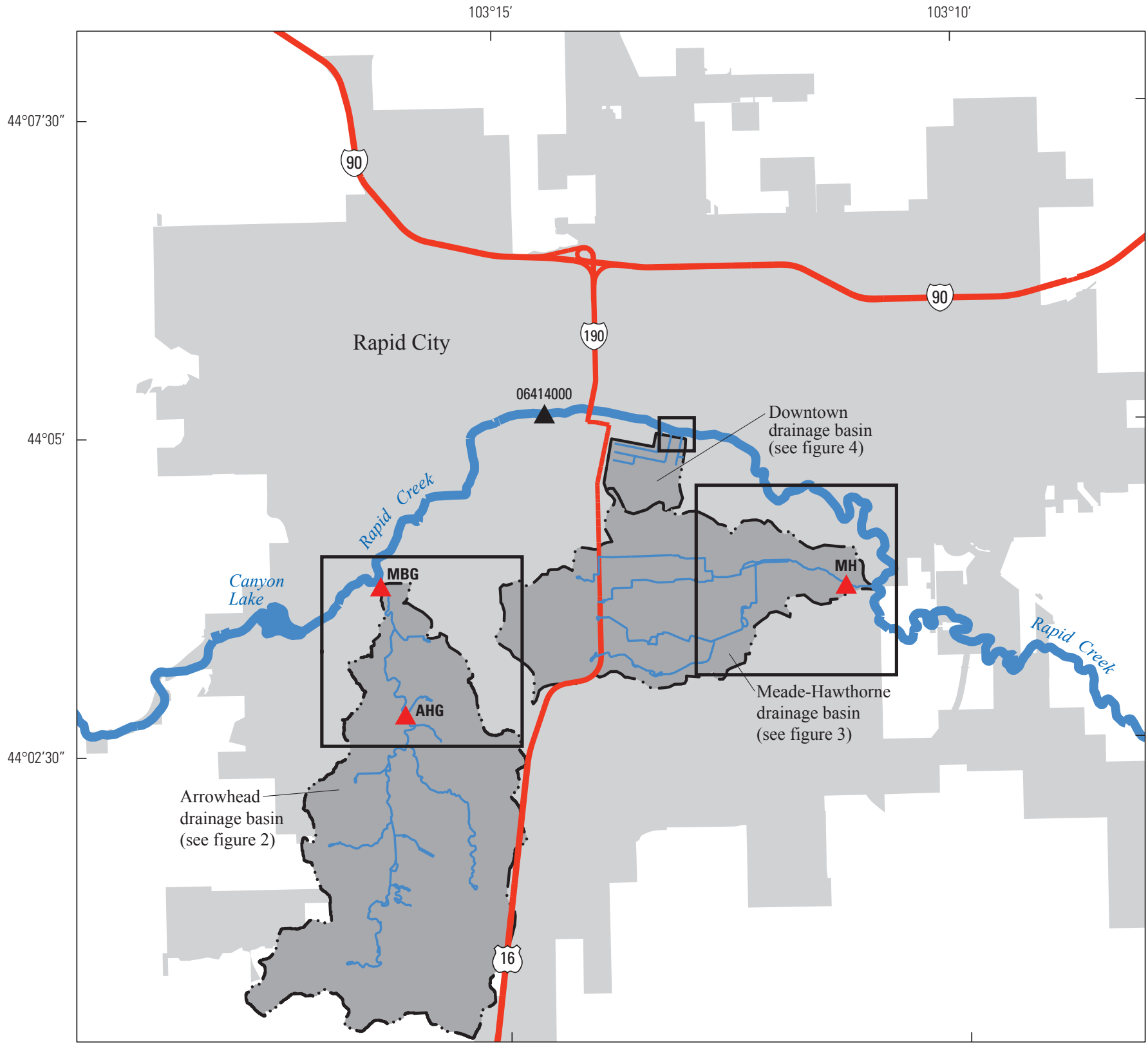

Base from U.S. Geological Survey digital data Universal Transverse Mercator projection Zone 13 North

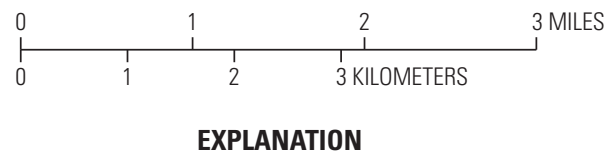

City limits

06414000 U.S. Geological Survey streamgage and identifier

AHG Monitoring site and identifier (table 1)

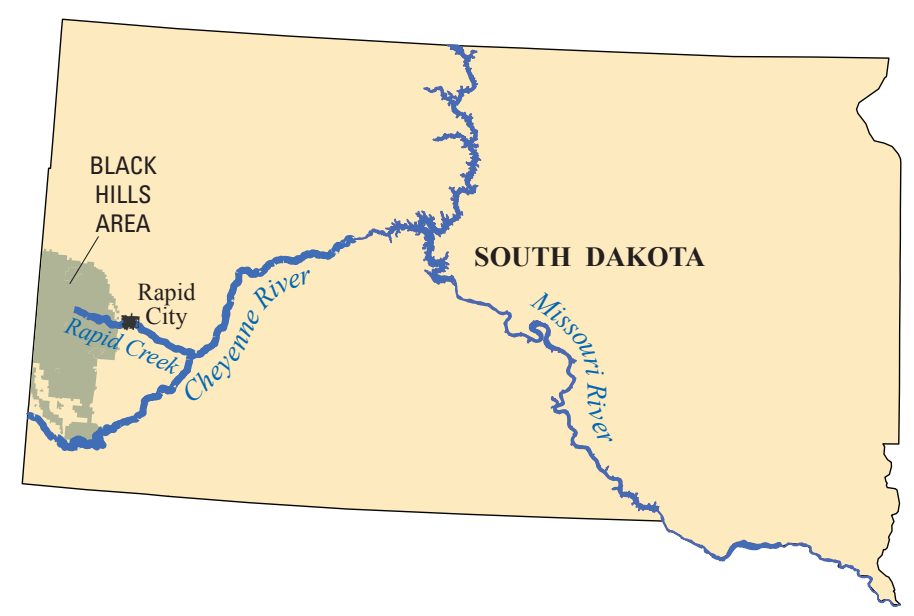

Figure 1. Location of U.S. Geological Survey streamgages, stormwater monitoring sites, and drainage areas, Rapid City, South Dakota. 
Two monitoring sites were located within the Arrowhead drainage basin: at Arrowhead Country Club (hereafter referred to as the "AHG site") and the basin outlet at Meadowbrook Golf Course (hereafter referred to as the "MBG site"; table 1, fig. 2). The AHG site is located downstream from the most developed areas of the Arrowhead drainage basin. The area between the AHG and MBG sites is predominately golf course land, which typically attenuates stormwater flow during runoff events.

\section{Meade-Hawthorne Drainage Basin}

The Meade-Hawthorne drainage basin is located in southcentral Rapid City and drains approximately $3.3 \mathrm{mi}^{2}$ upon entering Rapid Creek (figs. 1 and 3). The mean percentage of impervious area for the Meade-Hawthorne basin is 38 percent (Fry and others, 2011). The predominant land use/land cover is low-density residential (31 percent) followed by medium-density residential ( 25 percent), agricultural (15 percent), general commercial ( 9 percent), park and forest (9 percent), and small portions of neighborhood and office commercial, heavy and light industrial, and public. The conveyance structures in the Meade-Hawthorne drainage basin differ greatly from those in the Arrowhead drainage basin, with roughly 80 percent consisting of concrete channels and culverts, allowing for little to no infiltration. The Meade-Hawthorne monitoring site (hereafter referred to as the "MH site"; table 1) is located at Creek Drive near the basin outlet, about 0.20 mile (mi) upstream from the confluence with Rapid Creek (fig. 3).

\section{Downtown Drainage Basin}

The Downtown drainage basin consists of several small drainage networks originating from the highly urbanized areas of downtown Rapid City (figs. 1 and 4). The areas monitored in this study were the 1st, 2nd, and 3rd Street outfalls and their wetland channel BMPs. Collectively, the three outfalls have a contributing drainage area of about $0.42 \mathrm{mi}^{2}$ (table 2), with land use composed of 56 percent commercial, 16 percent high-density residential, 13 percent medium-density residential, and 15 percent parks or forest. Impervious area accounts for 50 percent of the 1st Street drainage area, 66 percent for the 2nd Street, and 93 percent of the 3rd Street drainage area (Fry and others, 2011). Before construction of the wetland channels in 2011, all stormwater from these basins discharged directly to Rapid Creek. Since construction of the wetland channels, stormwater enters the approximately 300 -foot (ft) long by $30-\mathrm{ft}$ wide channels by way of a flow divider structure (fig. 5), which routes flows into the wetland channel by way of an 18-inch diversion culvert (approximate free-flow capacity of $7.4 \mathrm{ft}^{3} / \mathrm{s}$ ). Larger stormwater flows discharge directly to Rapid Creek with an overflow weir at an elevation higher than the culvert top (fig. 5). Retention time through the wetlands is about $8-10$ minutes during the maximum inflow (table 2). At each wetland outflow, a concrete outlet weir maintains a shallow water level (about 1.5 -ft deep at weir) and allows for measurement of outflow to Rapid Creek (fig. 6). Monitoring sites were located at the inflow and outflow for each wetland channel. The 2nd Street wetland has substantially less retention volume ( 76 cubic feet $\left[\mathrm{ft}^{3}\right]$ ) than the other two wetlands $\left(1,100 \mathrm{ft}^{3}\right.$ for the 1 st and $3 \mathrm{rd}$ Street wetlands; table 2$)$. Retention volume is defined as water stored below the outlet weir elevation; detention volume is defined as water stored above the outlet weir elevation. During 2013-14, the retention pool for the 1st and 2nd Street wetlands would dry completely in the absence of precipitation events, whereas the 3rd Street wetland maintained a permanent pool fed by a nearly continuous trickle (less than $1 \mathrm{ft}^{3} / \mathrm{s}$ ) flow from the stormwater outfall through the diversion culvert.

Table 1. List of monitoring sites in the Arrowhead, Meade-Hawthorne, and Downtown drainage basins, Rapid City, South Dakota.

[ID, identifier; USGS, U.S. Geological Survey]

\begin{tabular}{|c|c|c|c|}
\hline Drainage basin & Short ID & USGS site ID & Site name \\
\hline \multirow[t]{2}{*}{ Arrowhead } & AHG & 440247103160400 & Arrowhead drainage at Arrowhead Country Club. \\
\hline & MBG & 440349103162000 & Arrowhead drainage at Meadowbrook Golf Course. \\
\hline Meade-Hawthorne & $\mathrm{MH}$ & 440344103111300 & Meade drainage at Creek Drive. \\
\hline \multirow[t]{6}{*}{ Downtown } & $1-\mathrm{IN}$ & 440457103130000 & 1st Street outfall wetland inlet at Rapid City, S. Dak. \\
\hline & 1-OUT & 440457103125600 & 1st Street outfall wetland outlet at Rapid City, S. Dak. \\
\hline & $2-\mathrm{IN}$ & 440458103130700 & 2nd Street outfall wetland inlet at Rapid City, S. Dak. \\
\hline & 2-OUT & 440457103130200 & 2nd Street outfall wetland outlet at Rapid City, S. Dak. \\
\hline & $3-\mathrm{IN}$ & 440500103131300 & 3rd Street outfall wetland inlet at Rapid City, S. Dak. \\
\hline & 3-OUT & 440458103130800 & 3rd Street outfall wetland outlet at Rapid City, S. Dak. \\
\hline
\end{tabular}




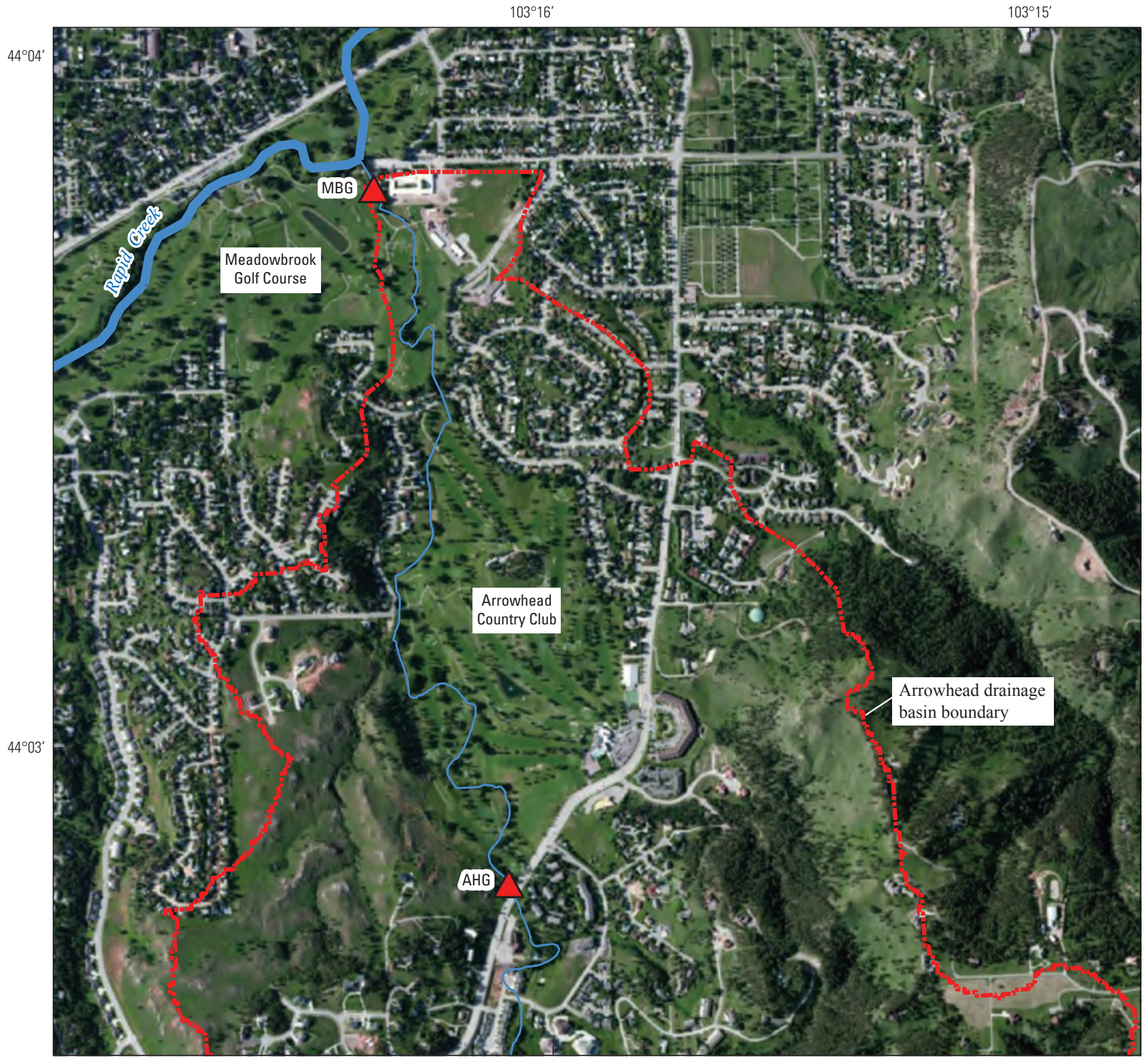

Base from U.S. Geological Survey digital data, various scales, variously dated

Map image is the intellectual property of Esri and is used herein under license. Copyright $(2015$ Esri and its licensors. All rights reserved

Universal Transverse Mercator projection Zone 13 North

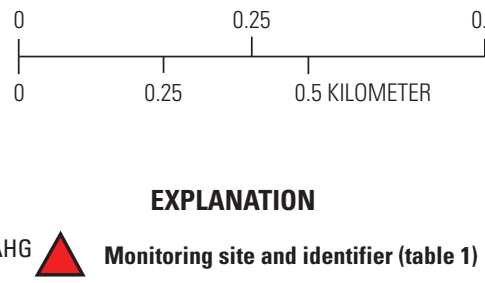

0.5 MILE

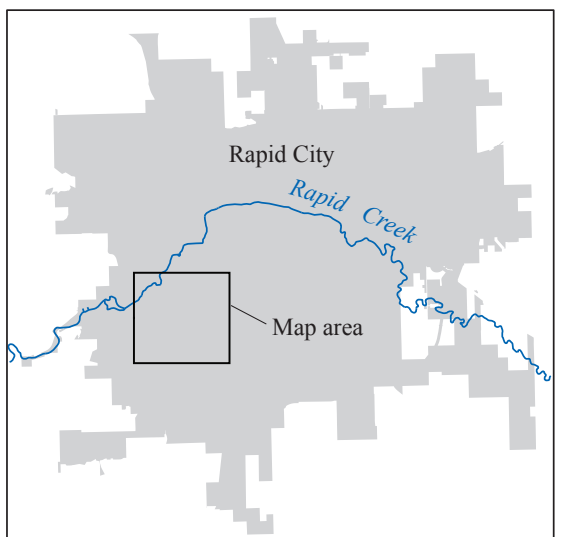

Figure 2. Monitoring sites in the Arrowhead drainage basin. 
$103^{\circ} 12^{\prime}$

$103^{\circ} 11^{\prime}$

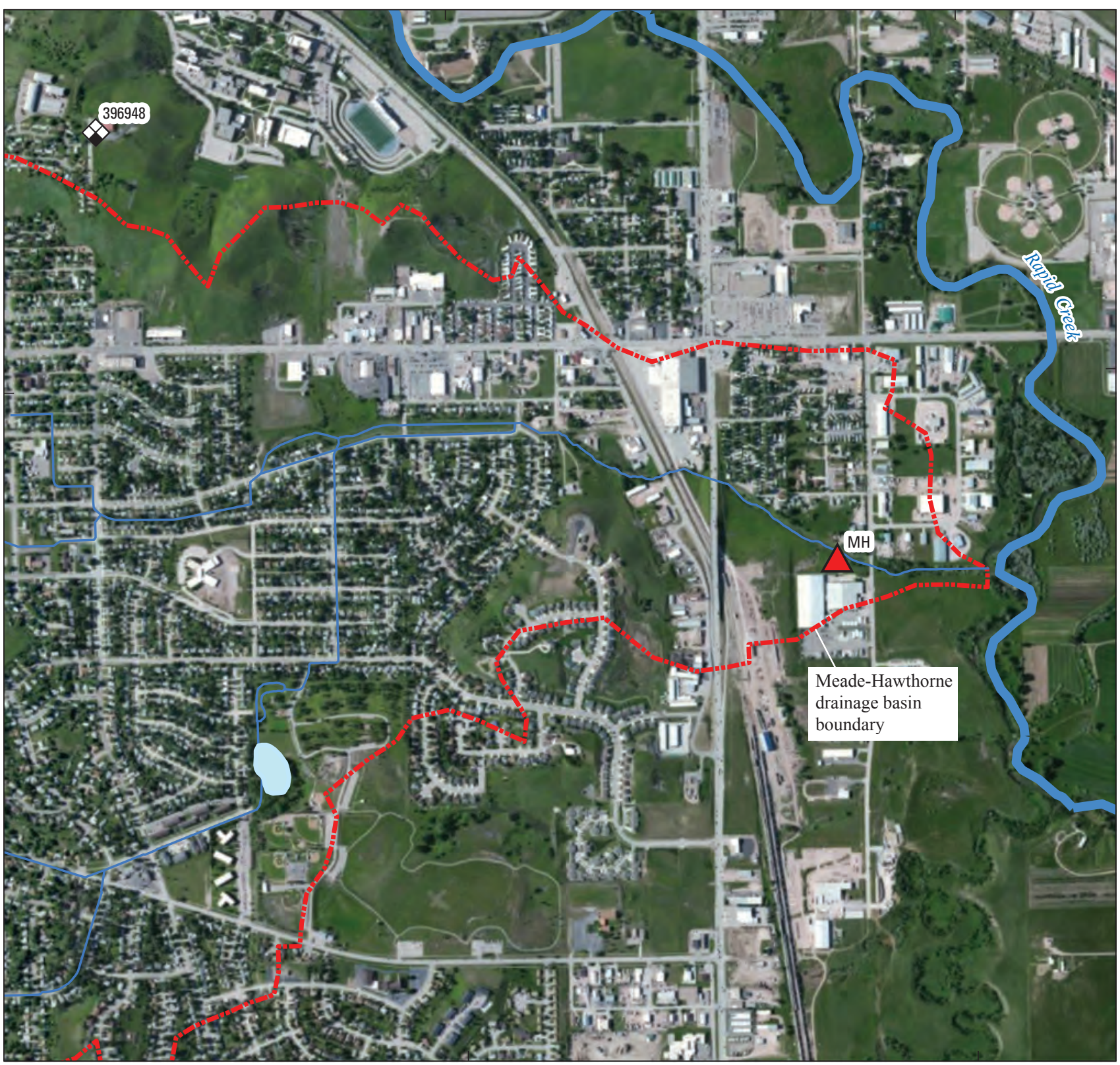

Base from U.S. Geological Survey digital data, various scales, variously dated

Map image is the intellectual property of Esri and is used herein under license. Copyright (c) 2015 Esri and its licensors. All rights reserved

Universal Transverse Mercator projection

Zone 13 North
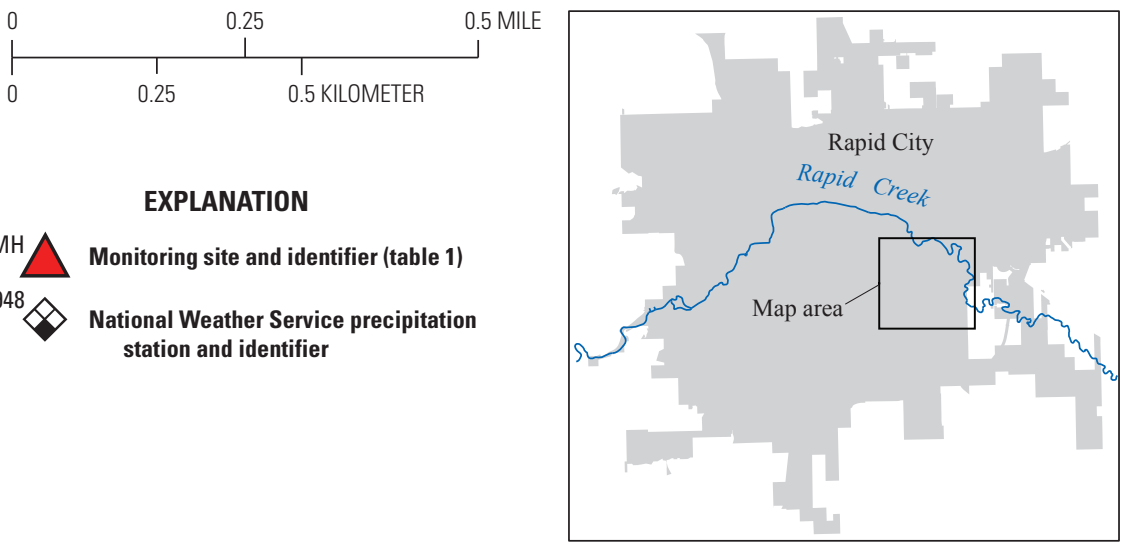

Figure 3. Monitoring site in the Meade-Hawthorne drainage basin. 


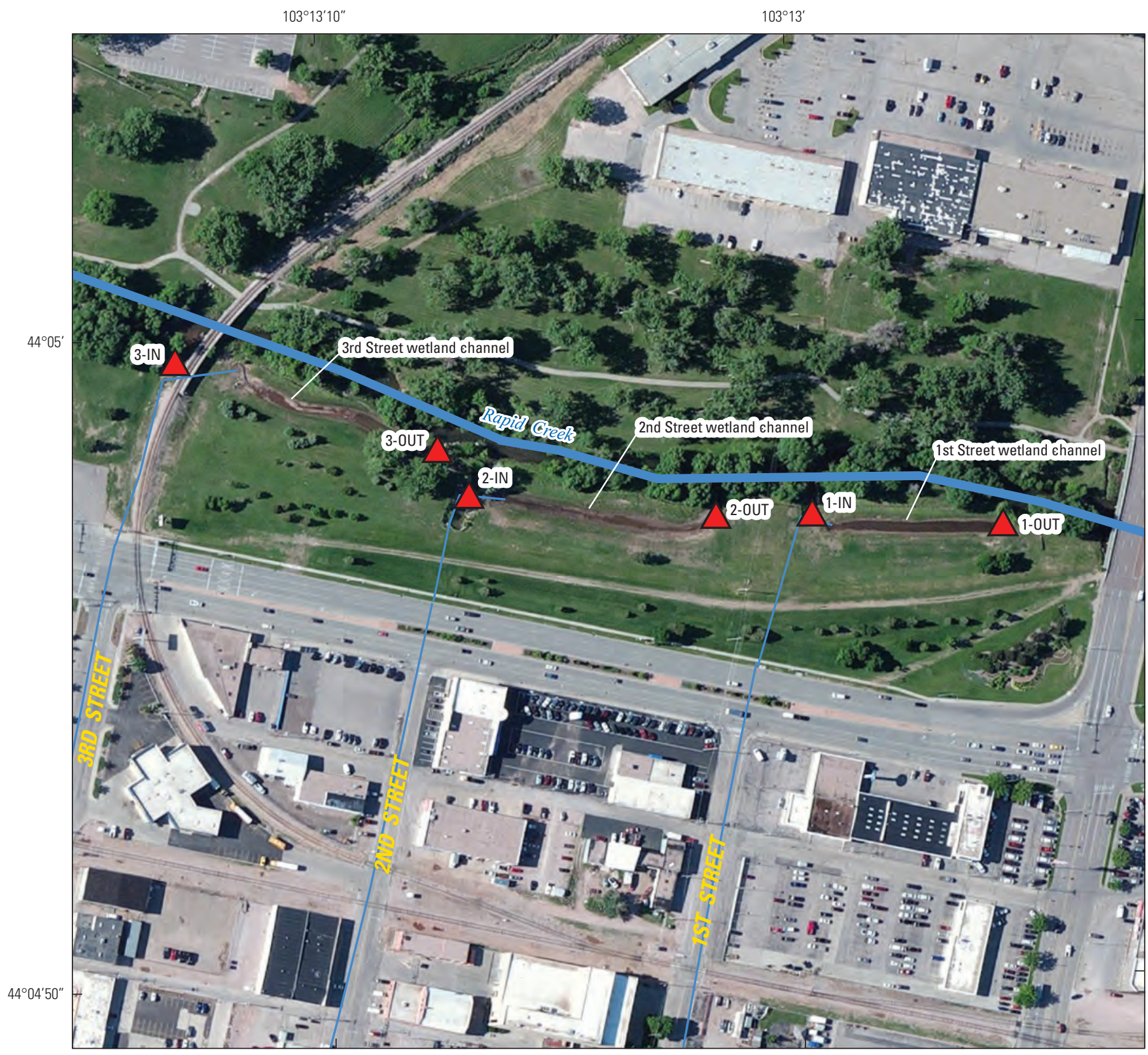

Base from U.S. Geological Survey digital data, various scales, variously dated

Map image is the intellectual property of Esri and is used herein under license. Copyright ( 2014 Esri and its licensors. All rights reserved

Universal Transverse Mercator projection Zone 13 North

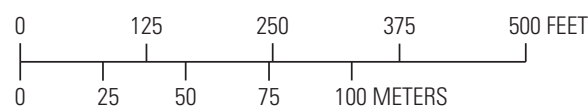

100 METERS

\section{EXPLANATION}

2-IN Monitoring site and identifier (table 1)

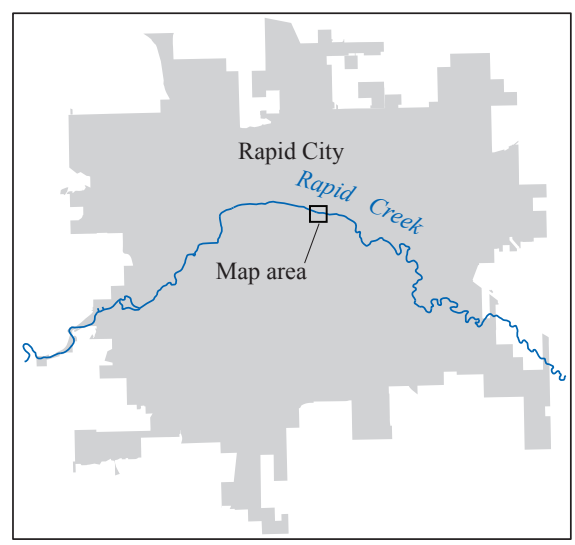

Figure 4. Wetland channels and monitoring sites for the 1st, 2nd, and 3rd Street outfalls in the Downtown drainage basin, Rapid City, South Dakota. 
Table 2. Select design information for three wetland channels located at the 1st, 2nd, and 3rd Street outfalls of the Downtown drainage basin.

$\left[\mathrm{mi}^{2}\right.$, square miles; $\mathrm{ft}^{3} / \mathrm{s}$, cubic feet per second; $\mathrm{ft}^{3}$, cubic feet; $\mathrm{ft}$, feet; min, minutes $]$

\begin{tabular}{lcccc}
\hline \multicolumn{1}{c}{ Characteristic } & Units & 1st Street outlet & 2nd Street outlet & 3rd Street outlet \\
\hline Drainage area & $\mathrm{mi}^{2}$ & 0.12 & 0.27 & 0.027 \\
Percent impervious surfaces & $\mathrm{percent}^{2}$ & 50 & 66 & 93 \\
Maximum outlet pipe discharge & $\mathrm{ft} / \mathrm{s}$ & 52 & 348 & 87 \\
Diversion pipe maximum discharge & $\mathrm{ft}^{3} / \mathrm{s}$ & 7.4 & 7.4 & 7.4 \\
Detention volume & $\mathrm{ft}^{3}$ & 2,800 & 3,200 & 3,400 \\
Retention volume & $\mathrm{ft}^{3}$ & 1,100 & 76 & 1,100 \\
Wetland channel surface area & $\mathrm{acres}^{3}$ & 0.13 & 0.25 & 0.18 \\
Wetland channel length & $\mathrm{ft}$ & 270 & 360 & 330 \\
Minimum retention time & $\mathrm{min}$ & 9 & 8 & 10 \\
\hline
\end{tabular}

${ }^{1}$ Minimum retention time for maximum diversion culvert discharge of $7.4 \mathrm{ft}^{3} / \mathrm{s}$.

\section{Previous Studies}

In the past 35 years, multiple studies have examined the quantity and quality of the runoff from storm events in the Rapid City area. Pirner and Harms (1978) performed a study to determine the potential of urban runoff as a source of pollution in Rapid Creek. The Nationwide Urban Runoff Program chose Rapid City as one of its locations for study during the early 1980s and tested for numerous water-quality constituents (U.S. Environmental Protection Agency, 1983). In a report to the South Dakota Department of Environment and Natural Resources and the City of Rapid City, Kenner and Craft (1997) described a study on different parts of the Rapid Creek drainage to assess the effects on the quality of the overall creek system. Krantz (2002) implemented a 2-year water-quality sampling program on Rapid Creek to investigate potential effects of stormwater runoff on the brown trout population. Results of the study by Krantz (2002) indicated that TSS and turbidity increase in Rapid Creek through the City of Rapid City to levels greater than those that could potentially pose a threat to trout health. Baker (2010) presented an early subset of the water-quality data for the Arrowhead drainage basin. Fisher (2011) evaluated the effectiveness of several BMP structures for the management of stormwater quantity and quality on the Rapid Creek drainage basin. Schiferl (2011) evaluated the potential contribution of bottom sediments as a source of fecal coliform bacteria in stormwater runoff in both the Arrowhead and Meade-Hawthorne drainage basins in Rapid City. Prann (2013) evaluated the effect of impervious surfaces on water quality using calibrated hydrologic models. All of these studies indicate that the TSS and fecal coliform concentrations in the stormwater runoff in the Arrowhead and Meade-Hawthorne drainage basins have the potential to adversely affect the quality of the waters in the Rapid Creek drainage basin.

\section{Methods}

The following sections describe the methods used for collection of stage and discharge information, collection and processing of water-quality samples, and development of event-mean concentrations. Datasets collected at the Arrowhead and Meade-Hawthorne monitoring sites differed slightly from those collected at the Downtown monitoring sites. For the Arrowhead sites, five to seven independent storm runoff events were sampled each year during 2008-11 and one storm event was sampled during 2012. For the Meade-Hawthorne sites, five to seven independent storm runoff events were sampled each year during 2010-11 and one storm event was sampled during 2012. Continuous stage and discharge information (15-minute intervals) was collected at the sites in the Arrowhead and Meade-Hawthorne drainage basins, allowing for calculation of event-mean concentrations. Precipitation estimates for each storm event at the Arrowhead sites was obtained from the AHG site (table 1), which was equipped with a tipping-bucket rain gage to measure storm precipitation totals in 0.01-inch increments. Precipitation estimates for the Meade-Hawthorne storm events were obtained from National Weather Service Station 396948 (fig. 3; National Oceanic and Atmospheric Administration, 2015). During 2013-14, waterquality data were collected at the 1st, 2nd, and 3rd Street outfalls of the Downtown drainage basin for approximately six storm runoff events each year. Precipitation totals for the Downtown drainage basin events were all similar (mean event total was 0.27 inches at National Weather Service Station 396948), but are not presented in this report. 
Diversion culvert

(to wetland channel)
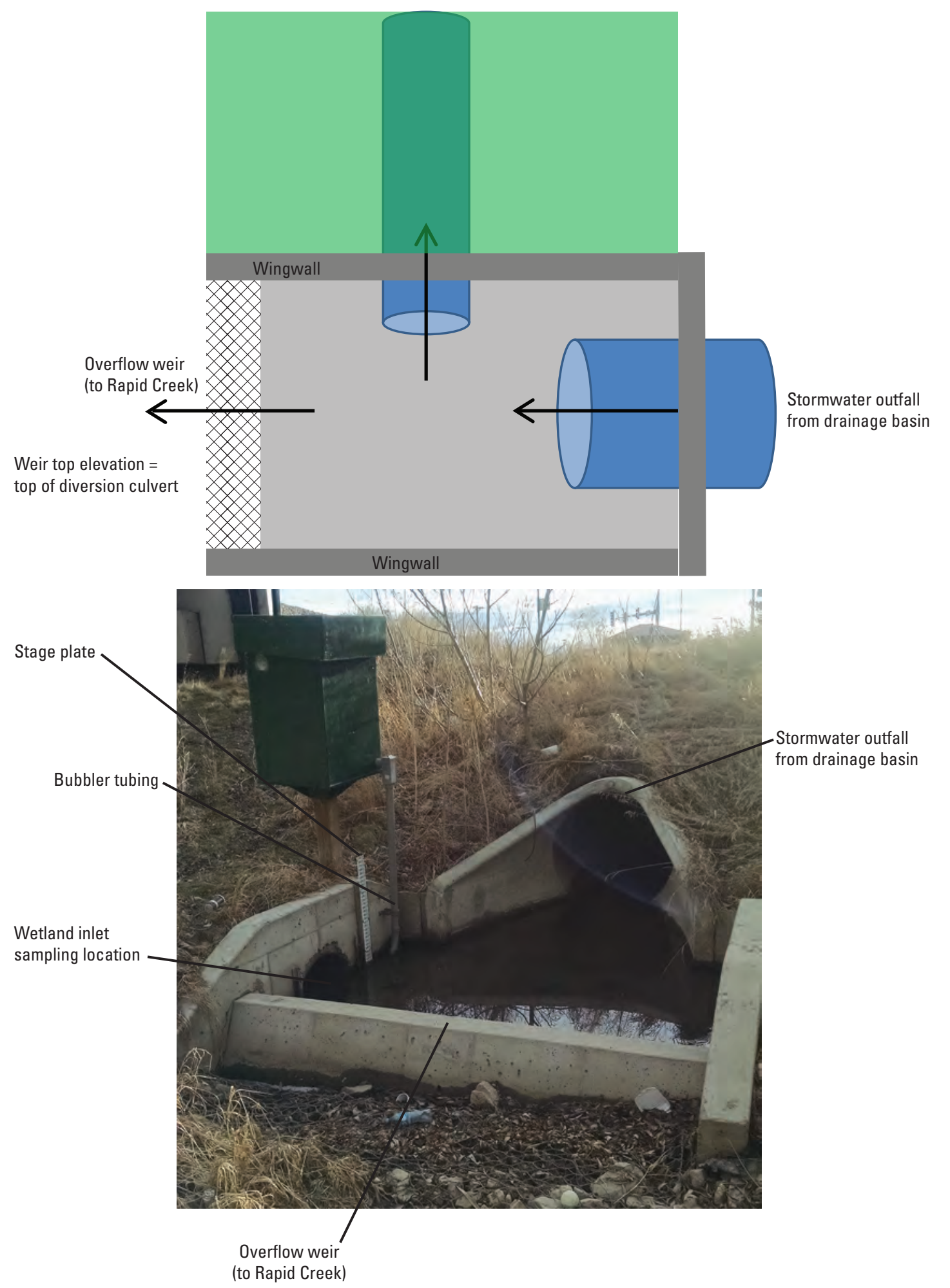

Figure 5. Flow divider structure located at the 3rd Street outfall of the Downtown drainage basin (monitoring site $3-I N)$. 


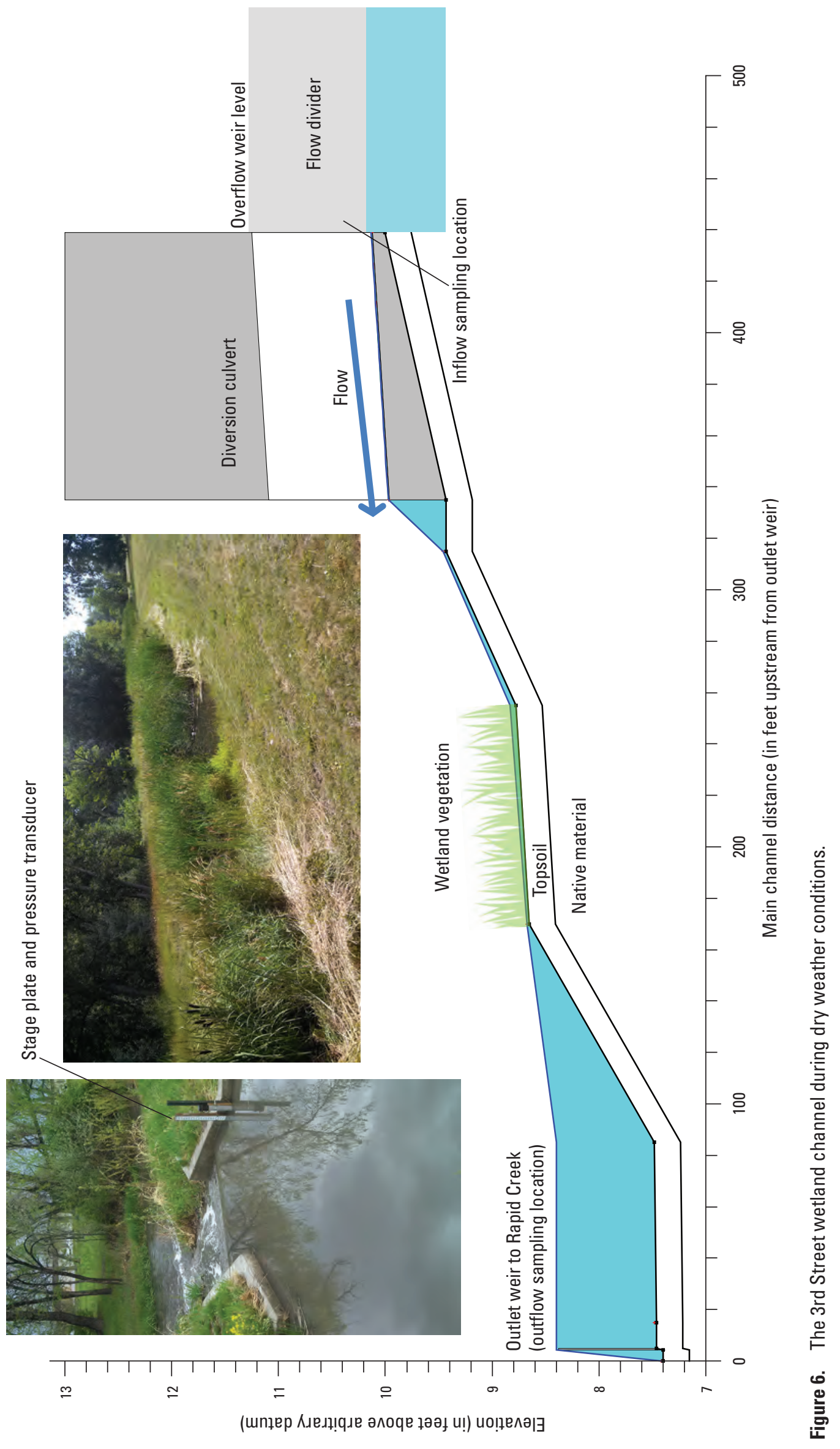




\section{Stage, Discharge, and Precipitation Measurements}

Equipment used to measure stage at monitoring sites included submerged pressure transducers, stage bubbler systems, and automated sampling devices using methods described in Sauer and Turnipseed, 2010). At the Arrowhead and Meade-Hawthorne sites, automated samplers with a submerged probe flow module were used for water-stage measurement and sample collection (fig. 7). Stage plates were mounted to posts driven into the streambank or concrete wingwalls of flow structures to be used for verification or correction of stage data. A stage-discharge rating curve was developed at each site using a series of open-channel discharge measurements (Turnipseed and Sauer, 2010) during the sampling period that was used to determine discharge during sample collection periods (appendix 1).

At the Downtown drainage basin sites, wetland inflow stage was monitored using a bubbler system. Wetland outflow stage was recorded using a non-vented submersible pressure transducer enclosed in a polyvinyl chloride stilling well corrected with a separate barometric pressure logger located in the gage housing at the inflow site. Continuous stage information (5-minute intervals) was collected at each of the three wetland inflow and outflow sites of the Downtown drainage basin; however, no inflow or outflow discharge information at the Downtown drainage basin is presented in this report. It was determined that all three inflow sites commonly experienced backwater conditions (when the culvert outflow was submerged at the entry to the wetland channels) during runoff events; therefore, accurate discharge information at the wetland inflow sites was not available.

Precipitation data were collected at the AHG site using a tipping bucket to measure precipitation to the nearest $0.1 \mathrm{inch}$ (U.S. Geological Survey, 2010) and data loggers to record the data at 10-minute intervals. Additional precipitation data were obtained from the National Weather Service Station 396948 (National Oceanic and Atmospheric Administration, 2015).

\section{Collection, Processing, and Analysis of Water Samples}

At the Arrowhead and Meade-Hawthorne sites, the automated samplers were programmed to collect samples when the stage increases above a certain baseline level, indicating the beginning of a runoff event. Sample intake lines consisted of 3/8-inch diameter Tygon ${ }^{\circledR}$ tubing with a stainless steel strainer connected at the intake point. The strainer was staked to the center of the channel in a downstream orientation about 6 to 12 inches above the stream bottom. Each automated sampler can fill twenty-four 1-liter high-density polyethylene (HDPE) bottles at user-defined intervals. After the bottles were filled by the automated sampler, they were transported to the USGS office laboratory in Rapid City for processing. Raw water from the 1-liter bottles was split into smaller aliquots and transported to the analyzing laboratory within 24 hours. For most storm events, at least four discrete samples were sent for laboratory analyses, covering all sections of the hydrograph (rising, peak, and falling). For more complicated hydrographs, such as multiple peaks, additional samples were submitted. A similar sampling approach was used at the Downtown drainage basin; however, most storm events were sampled manually by staff collecting grab samples directly into 1-liter HDPE bottles. Grab samples were obtained at wetland inflow sites by immersing the bottles in the center of flow at the upstream end of the diversion culvert (fig. 5). All bottles were rinsed with sample water immediately prior to collection of the sample for analyses. Grab samples at the wetland outflow sites followed a similar procedure, with samples collected on the upstream side of the weir center at a depth of about 6-12 inches from the water surface (fig. 6).

Water-quality constituents analyzed were TSS, chloride, nitrogen species (nitrate plus nitrite, ammonia, organic), phosphorus, E. coli, fecal coliform bacteria, cadmium, copper, lead, and zinc (table 3 ). These water-quality constituents were selected based on three factors: (1) the presence of a waterquality standard for the receiving waterbody (Rapid Creek); (2) whether or not the constituent was listed in table 2.1 of the "Rapid City Stormwater Quality Manual" (City of Rapid City, 2009), which presents literature-based removal efficiencies of selected pollutants for various BMPs; or (3) if the constituent was a pollutant that has been identified as frequently occurring in large concentrations by previous urban runoff literature (such as U.S. Environmental Protection Agency, 1983; Lopes and others, 1994). All water-quality constituents listed in table 3 were unfiltered analyses, with the exceptions of ammonia and nitrate plus nitrite.

Samples of TSS, chloride, and bacteria were analyzed at Energy Laboratories (Rapid City, S.Dak.). The TSS concentration was measured by taking a known volume of sample and passing it through a glass fiber filter disc and then drying the sample. The residue from the filter was weighed, which determined the concentration in mass per volume given in milligrams per liter (American Public Health Association, 2015). Chloride was measured using ion chromatography according to U.S. Environmental Protection Agency method 300.0 (Pfaff, 1993). Fecal coliform bacteria were analyzed by use of the m-FC agar medium membrane filtration method (section 9222D in American Public Health Association, 2015), quantified in colony forming units per 100 milliliters (cfu/100 mL). E. coli was determined by use of the enzyme substrate test (American Public Health Association, 2015), which uses a special medium that reacts to the $E$. coli and changes color, and concentration is given in most probable number per 100 milliliters $(\mathrm{mpn} / 100 \mathrm{~mL})$. Colony forming units and most probable number units have been used interchangeably (Wisconsin Department of Natural Resources, 2009) but are determined using different methods. Samples were analyzed for selected nutrients (nitrate, nitrite, ammonia, and orthophosphate) and metals (cadmium, copper, lead, and zinc) at the USGS National Water-Quality Laboratory (Lakewood, 


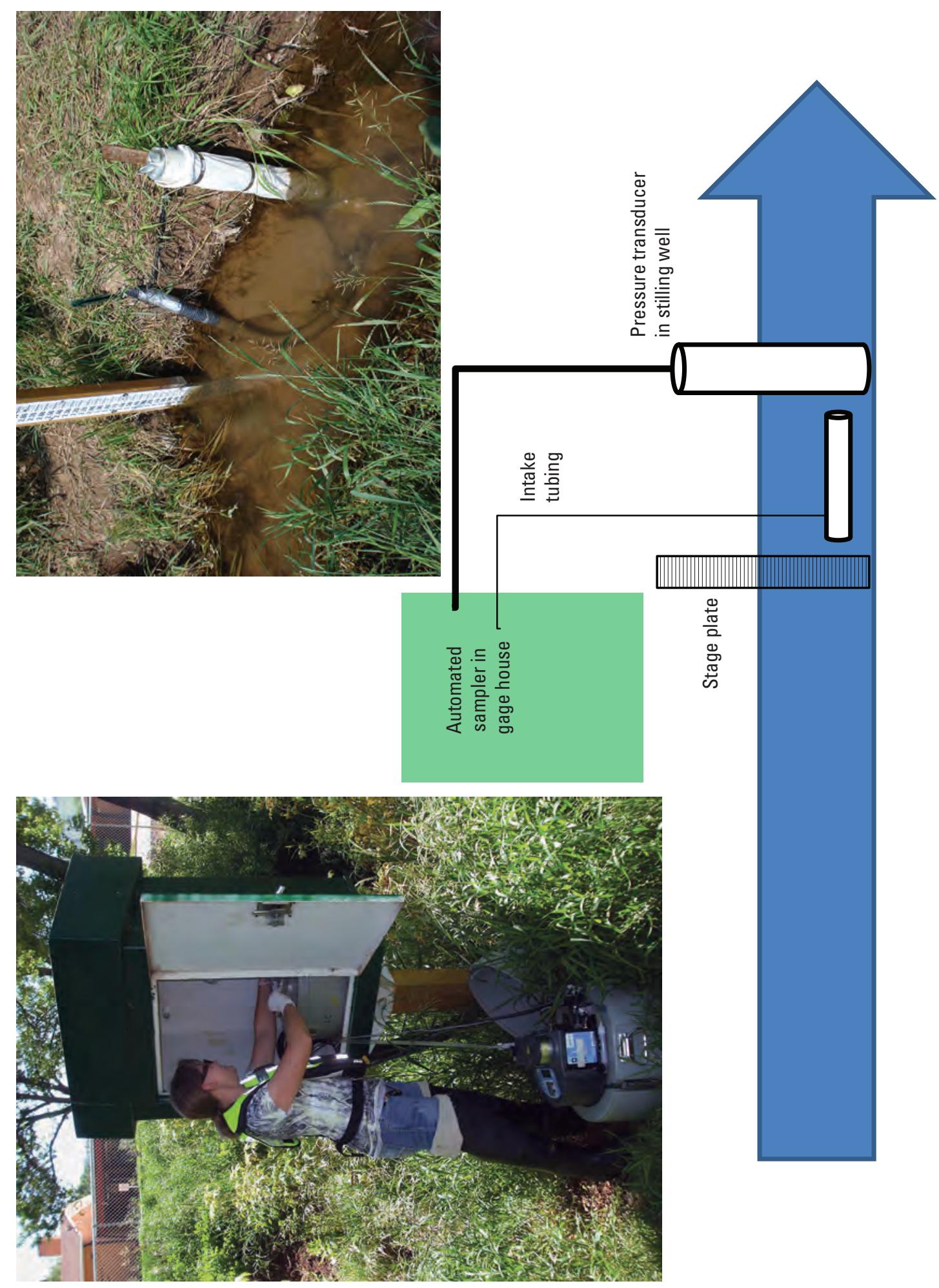

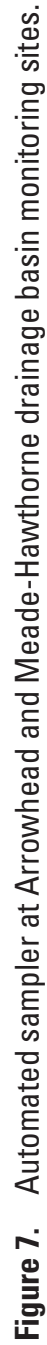


Table 3. Water-quality constituents measured in stormwater samples, and relevant standards or limits for Rapid Creek at Rapid City, South Dakota.

[USGS, U.S. Geological Survey; AH, Arrowhead; MH, Meade-Hawthorne; --, not measured or available; X, measured; $\mu \mathrm{S} / \mathrm{cm}$ at $25^{\circ} \mathrm{C}$, microsiemens per centimeter at 25 degrees Celsius; $\mathrm{mg} / \mathrm{L}$, milligrams per liter; $\mathrm{mg} / \mathrm{L}$ as N, milligrams per liter as nitrogen; $\mathrm{mpn} / 100 \mathrm{~mL}$; most probable number per $100 \mathrm{milliliters;}$ cfu/100 mL, colony forming units per 100 milliliters; $\mu \mathrm{g} / \mathrm{L}$, micrograms per liter]

\begin{tabular}{|c|c|c|c|c|c|c|}
\hline Constituent & $\begin{array}{c}\text { USGS } \\
\text { parameter } \\
\text { code }\end{array}$ & Units & $\begin{array}{c}\text { AH and MH } \\
\text { drainage basins } \\
(2008-12)\end{array}$ & $\begin{array}{c}\text { Downtown } \\
\text { drainage basin } \\
\text { (2013-14) }\end{array}$ & $\begin{array}{l}\text { Standard or } \\
\text { limit }^{1}\end{array}$ & Reference \\
\hline $\mathrm{pH}$ & 00400 & standard units & -- & $\mathrm{X}$ & $6.5-9.0$ & $\left({ }^{2}\right)$ \\
\hline Specific conductance & 00095 & $\mu \mathrm{S} / \mathrm{cm}$ at $25^{\circ} \mathrm{C}$ & -- & $\mathrm{X}$ & -- & -- \\
\hline Total suspended solids & 00530 & $\mathrm{mg} / \mathrm{L}$ & $\mathrm{X}$ & $\mathrm{X}$ & $30 / 53$ & $\left({ }^{2}\right)$ \\
\hline Chloride & 99220 & $\mathrm{mg} / \mathrm{L}$ & -- & $\mathrm{X}$ & $100 / 175$ & $\left({ }^{2}\right)$ \\
\hline Ammonia plus organic nitrogen & 00625 & $\mathrm{mg} / \mathrm{L}$ as $\mathrm{N}$ & -- & $\mathrm{X}$ & -- & -- \\
\hline Ammonia & 00608 & $\mathrm{mg} / \mathrm{L}$ as $\mathrm{N}$ & -- & $\mathrm{X}$ & $2.8 / 6.8$ & $\left({ }^{2}\right)$ \\
\hline Nitrate plus nitrite & 00631 & $\mathrm{mg} / \mathrm{L}$ as $\mathrm{N}$ & -- & $\mathrm{X}$ & $--/ 10$ & $\left({ }^{2}\right)$ \\
\hline Organic nitrogen & 00605 & $\mathrm{mg} / \mathrm{L}$ as $\mathrm{N}$ & -- & $\mathrm{X}$ & -- & -- \\
\hline Phosphorus & 00665 & $\mathrm{mg} / \mathrm{L}$ & -- & $\mathrm{X}$ & -- & -- \\
\hline Total nitrogen ${ }^{3}$ & 00600 & $\mathrm{mg} / \mathrm{L}$ as $\mathrm{N}$ & -- & $\mathrm{X}$ & -- & -- \\
\hline Escherichia coli & 31689 & $\mathrm{mpn} / 100 \mathrm{~mL}$ & $\mathrm{X}$ & -- & $126 / 235$ & $\left({ }^{2}\right)$ \\
\hline Fecal coliform bacteria & 61215 & $\mathrm{cfu} / 100 \mathrm{~mL}$ & $\mathrm{X}$ & $\mathrm{X}$ & $200 / 400$ & $\left({ }^{2}\right)$ \\
\hline Cadmium & 01027 & $\mu \mathrm{g} / \mathrm{L}$ & -- & $\mathrm{X}$ & $--/ 5$ & $\left({ }^{4}\right)$ \\
\hline Copper & 01042 & $\mu \mathrm{g} / \mathrm{L}$ & -- & $\mathrm{X}$ & $--/ 1,000$ & $\left({ }^{4}\right)$ \\
\hline Lead & 01051 & $\mu \mathrm{g} / \mathrm{L}$ & -- & $\mathrm{X}$ & $--/ 15$ & $\left({ }^{4}\right)$ \\
\hline Zinc & 01092 & $\mu \mathrm{g} / \mathrm{L}$ & -- & $\mathrm{X}$ & $--/ 5,000$ & $\left({ }^{4}\right)$ \\
\hline
\end{tabular}

${ }^{1}$ First value is the 30-day mean concentration / second value is the daily maximum concentration; $\mathrm{pH}$ values represent a range of acceptable values.

${ }^{2}$ Beneficial-use criteria from South Dakota Department of Environment and Natural Resources (2014).

${ }^{3}$ Total nitrogen is calculated as sum of ammonia plus organic nitrogen and nitrate plus nitrite.

${ }^{4}$ Drinking water standard from U.S. Environmental Protection Agency (2014).

Colorado) using standard methods (Fishman, 1993; Hoffman and others, 1996). Field measurements for $\mathrm{pH}$ and specific conductance were analyzed by USGS staff at the Rapid City office laboratory, using aliquots of raw water collected in the same bottles used for other constituent analyses (U.S. Geological Survey, variously dated).

\section{Event-Mean Concentrations}

Event-mean concentrations (EMCs) were calculated where discharge and water-quality data were sufficient to represent a storm hydrograph (typically defined as having at least three samples - one from the rising limb, one near the peak, and one during the falling limb). The EMCs were calculated only for sites in the Arrowhead and Meade-Hawthorne drainage basins. The EMC is a flow-weighted concentration, calculated as the pollutant load (in mass units) divided by the total flow volume (U.S. Environmental Protection Agency, 1983) as shown in equation 1:

$$
\begin{gathered}
E M C=\sum V C / \sum V=\sum\left[\left(Q_{i}+Q_{i-1}\right) / 2\right]\left(t_{i}-t_{i-1}\right)\left[\left(C_{i}+C_{i-1}\right) / 2\right] / \\
\sum\left[\left(Q_{i}+Q_{i-1}\right) / 2\right]\left(t_{i}-t_{i-1}\right)
\end{gathered}
$$

where

$V \quad$ is the flow volume, in cubic feet;

$C_{i} \quad$ is the pollutant (for example, TSS) concentration, in milligrams per liter, at time $t_{i}$, in seconds; and

$Q_{i} \quad$ is the flow, in cubic feet per second, at time $t_{i}$, in seconds.

Estimates of $E M C$ can be converted to event load (in milligrams) or basin yield (load divided by drainage area, in milligrams per square mile). 


\section{Quality Assurance and Quality Control}

A quality-assurance/quality-control approach was used to identify possible cases of random or systemic errors in the field sampling, shipping, and laboratory analyses. Qualityassurance measures include using standard procedures for discharge measurement and water-quality sample collection according to the USGS National Field Manual (U.S. Geological Survey, variously dated). Water-level readings were inspected during each field visit for agreement between staff gages and data stored on monitoring equipment. Tubing and bottles used in automated sampling equipment were routinely cleaned as described in the USGS National Field Manual (U.S. Geological Survey, variously dated) or replaced following sampling events. For water-quality samples, fieldequipment blank and sequential replicate samples were used to determine the potential for sample contamination.

Field-equipment blank samples were collected at sites by passing analyte-free water through the collection and processing equipment used for the environmental samples and by using procedures identical to those used to collect and process the environmental samples. Constituent concentrations less than the minimum reporting level (MRL) in field-equipment blank samples indicate that the overall process of sample collection, processing, and laboratory analysis was free of substantial contamination. The MRL is the lowest measured concentration of a constituent that may be reliably reported from the use of a given analytical method (Timme, 1995). Sporadic, infrequent detections at concentrations near the MRL probably represent contamination from sample collection, processing, or shipping that is not likely to cause bias in the study results. Consistent detections in the field-equipment blank samples at concentrations within the range of concentrations in the environmental samples indicate that environmental concentrations need to be qualified or omitted from study results. Field-equipment blank samples were collected with 11 samples for analyses of fecal coliform bacteria, 8 samples for analyses of TSS, and 7 samples for analyses nutrients and metals. Fecal coliform was detected in 1 of 11 blank samples at a concentration of $200 \mathrm{cfu} / 100 \mathrm{~mL}$; all TSS concentrations in blank samples were less than the MRL. Ammonia was detected at small concentrations (less than $[<] 0.021$ milligrams per liter $[\mathrm{mg} / \mathrm{L}])$ in 3 of 7 blank samples, nitrate plus nitrite was detected in 1 of 7 blank samples at a concentration of $0.212 \mathrm{mg} / \mathrm{L}$, and copper was detected in 1 of 7 blank samples at a concentration of 3.5 micrograms per liter $(\mu \mathrm{g} / \mathrm{L})$. These detections were characterized as infrequent, and concentrations were near the MRLs; no further action for censoring of the environmental concentration data was taken.

Precision of analytical results for field replicate samples may be affected by numerous sources of potential variability in field and laboratory processes, including sample collection, sample processing and handling, and laboratory preparation and analysis. Analyses of field replicate samples, therefore, can indicate the reproducibility of environmental data and provide information on the variability associated with sample collection and analysis. Eight field replicate samples were analyzed for fecal coliform bacteria, six replicate samples were analyzed for TSS, four replicate samples were analyzed for $E$. coli, and one replicate sample was analyzed for chloride, nutrients, and metals. Relative percent difference was calculated as the difference in concentration divided by mean concentration multiplied by 100 for the environmental/replicate pair. The median relative percent differences for all environmental/replicate pairs for both fecal coliform and E. coli bacteria were about 30 percent, indicating fairly large variability with field and laboratory processes. The median relative percent difference for TSS was 7 percent. The relative percent differences for the environmental/replicate pair for chloride, nutrients, and metals were all less than 5 percent, indicating satisfactory data quality control on these constituents.

\section{Water-Quality Characteristics of Stormwater}

Complete water-quality results and associated discharge estimates (where available) are presented in appendix 1. The EMCs and statistical summaries are presented for the Arrowhead and Meade-Hawthorne drainage basins in the following sections to provide a characterization of the stormwater quality transported from these basins. Statistical summaries of concentration data for the 1st, 2nd, and 3rd Street outfall wetlands in the Downtown drainage basin are presented to provide a comparison to Arrowhead and Meade-Hawthorne conditions. In addition, a summary of concentration reductions between inflow and outflow monitoring sites at the wetlands are presented to describe constituent removal (or addition) relevant to this type of BMP. The EMCs from the Downtown drainage basin are not presented because accurate discharge estimates were not obtained from the outfalls (inflow to the wetlands was affected by variable backwater conditions).

\section{Arrowhead and Meade-Hawthorne Drainage Basins}

At the three monitoring sites in the Arrowhead and Meade-Hawthorne drainage basins, a total of 357 waterquality samples were collected during 2008-12. At the AHG site, 190 samples were collected during 20 different storm events, 76 samples were collected at the MBG site during 9 different storm events, and 91 samples were collected at the $\mathrm{MH}$ site during 12 different storm events. Water-quality results for TSS, fecal coliform bacteria, and E. coli indicate substantial sediment and bacteria transport from these basins (table 4). All EMCs exceeded the TSS and bacteria beneficialuse criteria for Rapid Creek (table 3 ), typically by 1-2 orders of magnitude. 
Table 4. Event-mean concentrations of total suspended solids, fecal coliform bacteria, and Escherichia coli for the Arrowhead and Meade-Hawthorne drainage basins, 2008-12.

[TSS, total suspended solids; mg/L, milligrams per liter; cfu/100 mL, colony forming units per 100 milliliters; mpn/100 mL, most probable number per $100 \mathrm{mil}$ liliters, --, not available]

\begin{tabular}{|c|c|c|c|c|c|}
\hline Date & $\begin{array}{l}\text { Short identifier } \\
\text { (table 1) }\end{array}$ & $\begin{array}{c}\text { Event precipitation } \\
\text { (inches) }{ }^{1}\end{array}$ & $\begin{array}{c}\text { TSS } \\
(\mathrm{mg} / \mathrm{L})\end{array}$ & $\begin{array}{l}\text { Fecal coliform bacteria } \\
\text { (cfu/100 mL) }\end{array}$ & $\begin{array}{c}\text { Escherichia coli } \\
(\mathrm{mpn} / 100 \mathrm{~mL})\end{array}$ \\
\hline $07 / 23 / 2008$ & AHG & 0.86 & 1,600 & $\left({ }^{2}\right)$ & -- \\
\hline $04 / 16 / 2009$ & AHG & 0.34 & 160 & $\left({ }^{2}\right)$ & -- \\
\hline 05/07/2009 & $\mathrm{AHG}$ & 0.13 & 260 & 1,000 & -- \\
\hline $06 / 18 / 2009$ & AHG & 0.27 & 1,900 & 10,000 & -- \\
\hline $06 / 26 / 2009$ & AHG & 0.54 & 1,200 & 37,000 & -- \\
\hline $07 / 13 / 2009$ & AHG & 0.43 & 200 & 11,000 & -- \\
\hline $05 / 10 / 2010$ & AHG & 2.33 & 120 & 1,100 & 540 \\
\hline 08/03/2010 & AHG & 1.39 & 950 & 21,000 & 9,900 \\
\hline $07 / 25 / 2011$ & AHG & 0.42 & 280 & 300,000 & 53,000 \\
\hline $07 / 27 / 2011$ & AHG & 0.80 & 1,200 & 23,000 & 31,000 \\
\hline 08/07/2011 & AHG & 0.83 & 610 & 12,000 & 8,400 \\
\hline 09/01/2011 & $\mathrm{AHG}$ & 0.27 & 170 & 26,000 & 14,000 \\
\hline $10 / 06 / 2011$ & AHG & 0.30 & 110 & 59,000 & 37,000 \\
\hline 05/19/2012 & AHG & 0.43 & 220 & 2,900 & -- \\
\hline $06 / 26 / 2009$ & MBG & 0.54 & 600 & 28,000 & -- \\
\hline 07/13/2009 & MBG & 0.43 & 260 & 150,000 & -- \\
\hline $05 / 19 / 2012$ & MBG & 0.43 & 32 & 1,000 & -- \\
\hline $06 / 10 / 2010$ & $\mathrm{MH}$ & 0.09 & 130 & 37,000 & 21,000 \\
\hline $06 / 22 / 2010$ & $\mathrm{MH}$ & 0.33 & 880 & 86,000 & 26,000 \\
\hline $07 / 11 / 2010$ & $\mathrm{MH}$ & 0.25 & 76 & 27,000 & 20,000 \\
\hline $07 / 19 / 2010$ & MH & 0.58 & 1,500 & 39,000 & 22,000 \\
\hline 08/03/2010 & $\mathrm{MH}$ & 1.04 & 1,100 & 49,000 & 22,000 \\
\hline 09/09/2010 & MH & 0.71 & 1,400 & 40,000 & 22,000 \\
\hline 06/09/2011 & $\mathrm{MH}$ & 0.56 & 320 & 12,000 & 14,000 \\
\hline $07 / 01 / 2011$ & $\mathrm{MH}$ & 0.32 & 410 & 29,000 & 21,000 \\
\hline $07 / 25 / 2011$ & MH & 0.17 & 300 & 27,000 & 21,000 \\
\hline 09/01/2011 & $\mathrm{MH}$ & 0.29 & 700 & 31,000 & 21,000 \\
\hline $10 / 06 / 2011$ & $\mathrm{MH}$ & 0.48 & 490 & 24,000 & 28,000 \\
\hline 05/19/2012 & $\mathrm{MH}$ & 0.60 & 540 & 3,500 & -- \\
\hline
\end{tabular}

${ }^{1}$ For AHG and MBG sites, precipitation is from AHG site. For MH site, precipitation is from National Weather Service station 396948.

${ }^{2}$ Bacteria dilutions at laboratory were too low to provide quantitative concentrations. 
Comparing concentrations between the Arrowhead and Meade-Hawthorne drainage basins, median EMCs for TSS were more than two times greater at the Meade-Hawthorne outlet at site $\mathrm{MH}(520 \mathrm{mg} / \mathrm{L})$ than the Arrowhead outlet at site MBG (200 mg/L; table 5 and fig. 8). Median EMCs for fecal coliform bacteria also were greater at site $\mathrm{MH}$ $(30,000 \mathrm{cfu} / 100 \mathrm{~mL})$ than at site MBG $(17,000 \mathrm{cfu} / 100 \mathrm{~mL})$. Median EMCs for E. coli were about three times greater at site $\mathrm{MH}(21,000 \mathrm{mpn} / 100 \mathrm{~mL})$ than at site MBG $(7,200 \mathrm{mpn} / 100 \mathrm{~mL})$. The EMCs for fecal coliform bacteria and E. coli were far less variable in the Meade-Hawthorne drainage basin (site $\mathrm{MH}$ ) compared to the Arrowhead drainage basin (sites AHG and MBG), as shown by the smaller interquartile ranges (boxes) in figure 8. The bacteria EMC data are not normally distributed (Kolmogorov-Smirnoff test, significance level less than 0.05; Haan, 1977); thus, the median statistic represents a better measure of central tendency than does the mean value. The greater EMCs for TSS and bacteria in the Meade-Hawthorne drainage basin may be explained by differences in land use and conveyance channels. The MeadeHawthorne drainage basin is much more urbanized than the Arrowhead drainage basin (38 and 9.6 percent impervious, respectively). The presence of more vegetated channels in the Arrowhead drainage basin (in contrast to the concrete structures predominantly found in the Meade-Hawthorne drainage basin) allows for passive treatment of stormwater.

Comparing the two sites within the Arrowhead drainage basin, median EMCs for TSS were similar between the AHG and MBG sites (240 and $200 \mathrm{mg} / \mathrm{L}$, respectively; table 5). The median EMCs for fecal coliform bacteria were lower at the upstream AHG site than at the downstream MBG site $(12,000$ and 17,000 cfu/100 mL, respectively); however, median EMCs for $E$. coli were much lower at site MBG $(7,200 \mathrm{mpn} / 100 \mathrm{~mL})$ than at site AHG $(16,000 \mathrm{mpn} / 100 \mathrm{~mL})$. The drainage area immediately upstream from the AHG site is predominantly low- to medium-density residential land use that contributes stormwater runoff from impervious surfaces. The intervening drainage area between the AHG and MBG sites contains about 25 percent low- to medium-density residential land use. Although the predominant park and forest land use in this reach helps attenuate the stormwater flows, no instream BMPs have been designed to reduce pollutant concentrations, as evidenced by the similarity between EMC distributions for TSS and fecal coliform bacteria at the two sites.

To gain a better understanding of the co-occurrence of stormwater pollutants, correlations between monitored pollutant concentrations were examined. Several other case studies have documented the relation of sediment (turbidity) concentration to bacterial density in perennial streams (Lawrence, 2012; Rasmussen and Ziegler, 2003). In these studies, turbidity values were shown to be a statistically significant predictor of bacteria concentrations. For considerations involving stormwater BMPs, it is often assumed that reductions in sediment also will result in reductions of bacteria and other pollutants. At the Arrowhead and Meade-Hawthorne sites, the relation between TSS and fecal coliform bacteria concentrations generally was poor (fig. $9 A$ ), as indicated by the low coefficients of determination $\left(R^{2}\right)$ for the multivariate regression models (Helsel and Hirsch, 2002) that ranged from 0.047 for site $\mathrm{MH}$ to 0.42 for site MBG. The strength of correlation increases as $\mathrm{R}^{2}$ approaches a value of 1 . The TSS concentration would be a poor surrogate for bacteria concentration based on the data collected at these sites. These data indicate that control or treatment of sediment in stormwater may not result in a corresponding reduction of bacteria. The relation between $E$. coli and fecal coliform bacteria indicated a much stronger correlation $\left(R^{2}\right.$ values ranging from 0.45 to 0.87 , fig. $9 B$ ), indicating that a monitoring program for either bacteria type could help characterize bacteriological loads of the other type of bacteria. The amount of precipitation during each storm event does not seem to be an important factor for the TSS EMCs ( $R^{2}$ values ranging from 0.021 to 0.42 , fig. $9 C$ ), indicating that a variety of rainfall-event volumes (storm totals) were capable of delivering large storm-event TSS concentrations.

\section{Downtown Drainage Basin}

Water-quality information for the 118 samples collected from the Downtown drainage basin is presented in appendix 1, and statistical summaries are presented in table 6 and figure 10. The number of samples collected at each site varied from 8 to 29 . More samples were collected from wetland inflow sites than wetland outflow sites. During some events, personnel or equipment limitations did not allow for all sites to be sampled, and priority was placed on the inflow locations to more accurately characterize the water quality originating from the Downtown drainage basin.

A comparison of concentration data in samples collected from sites in the Downtown drainage basin to relevant standards indicated that stormwater from the Downtown drainage basin exceeded criteria for fecal coliform bacteria and TSS, but concentrations generally were below standards for nutrients and metals. Median concentrations of fecal coliform bacteria at all wetland inflows and outflows (table 6) were an order of magnitude greater than the daily maximum beneficialuse criterion for Rapid Creek (400 cfu/100 mL; table 3). Median TSS concentrations were greater than the daily maximum beneficial-use criterion $(53 \mathrm{mg} / \mathrm{L})$ at the wetland inflow sites, but median concentrations were greatly reduced at the outflow sites. The median TSS concentrations at the 1st, 2nd, and 3rd Street wetland outflow sites were 180, 83, and $44 \mathrm{mg} / \mathrm{L}$, respectively, with the latter value less than the daily maximum beneficial-use criterion (tables 3 and 6). Chloride concentrations typically were greater at wetland outflow sites than inflow sites, but median concentrations were all below the daily maximum beneficial-use criteria of $175 \mathrm{mg} / \mathrm{L}$. Ammonia and nitrate plus nitrite concentrations were all about an order of magnitude below relevant standards. Compared to drinking-water standards (table 3; U.S. Environmental Protection Agency, 2014), most metal concentrations were well below 
Table 5. Statistical summary of event-mean concentrations for total suspended solids, fecal coliform, and Escherichia coli for the Arrowhead and Meade-Hawthorne drainage basins, 2008-12.

[TSS, total suspended solids; mg/L, milligrams per liter; cfu/100 mL, colony forming units per 100 milliliters; $\mathrm{mpn} / 100 \mathrm{~mL}$, most probable number per 100 milliliters]

\begin{tabular}{ccrcc}
\hline $\begin{array}{c}\text { Short identifier } \\
\text { (table 1) }\end{array}$ & Statistic & $\begin{array}{c}\text { TSS } \\
\text { (mg/L) }\end{array}$ & $\begin{array}{c}\text { Fecal coliform bacteria } \\
\text { (cfu/100 } \mathbf{~ m L})\end{array}$ & $\begin{array}{c}\text { Escherichia coli } \\
\text { (mpn/100 mL) }\end{array}$ \\
\hline AHG & Minimum & 74 & 1,000 & 540 \\
& Median & 240 & 12,000 & 16,000 \\
& Mean & 500 & 35,000 & 20,000 \\
& Maximum & 1,900 & 300,000 & 53,000 \\
MBG & Minimum & 32 & 1,000 & 430 \\
& Median & 200 & 17,000 & 7,200 \\
& Mean & 330 & 34,000 & 8,400 \\
& Maximum & 840 & 150,000 & 23,000 \\
MH & Minimum & 76 & 3,500 & 14,000 \\
& Median & 520 & 30,000 & 21,000 \\
& Mean & 660 & 34,000 & 22,000 \\
& Maximum & 1,500 & 86,000 & 28,000 \\
\hline
\end{tabular}
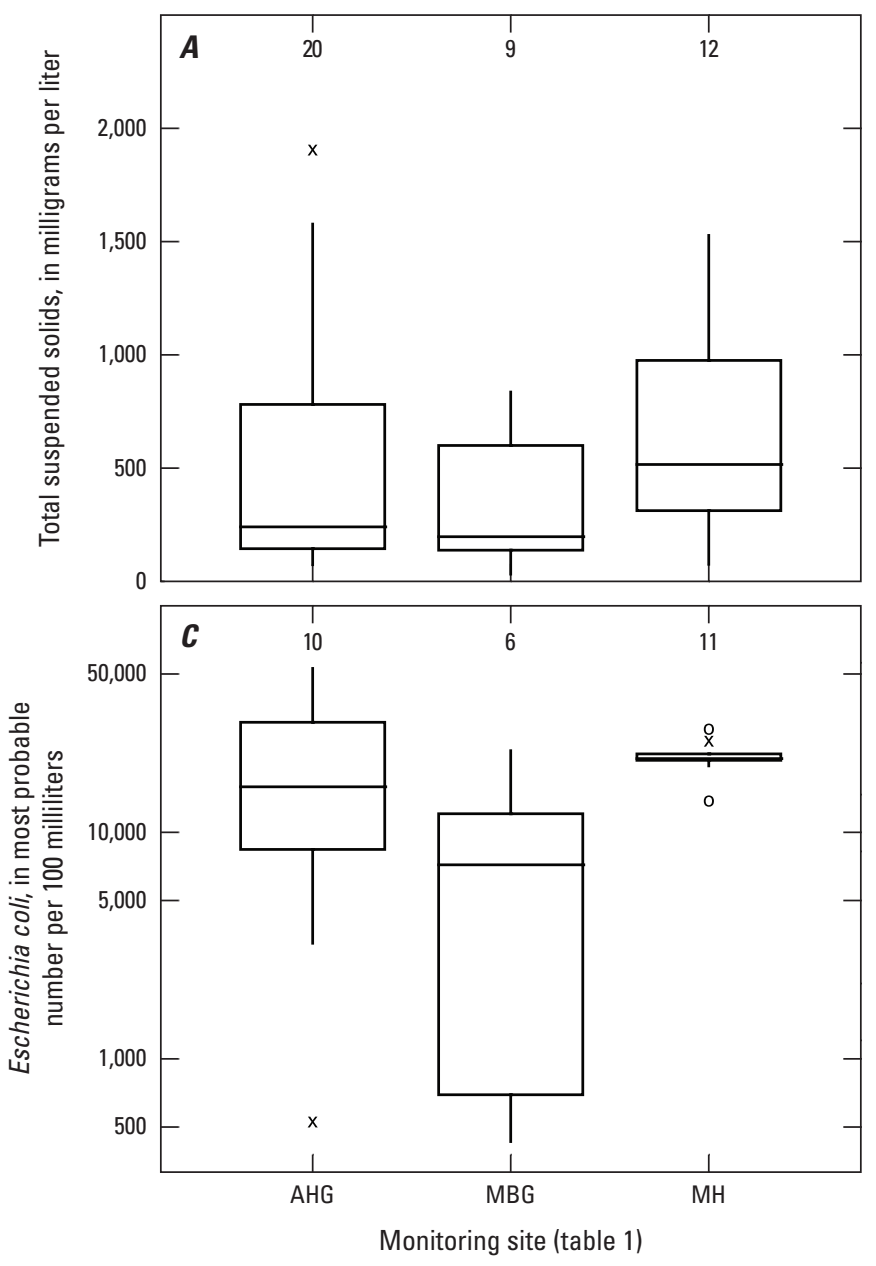

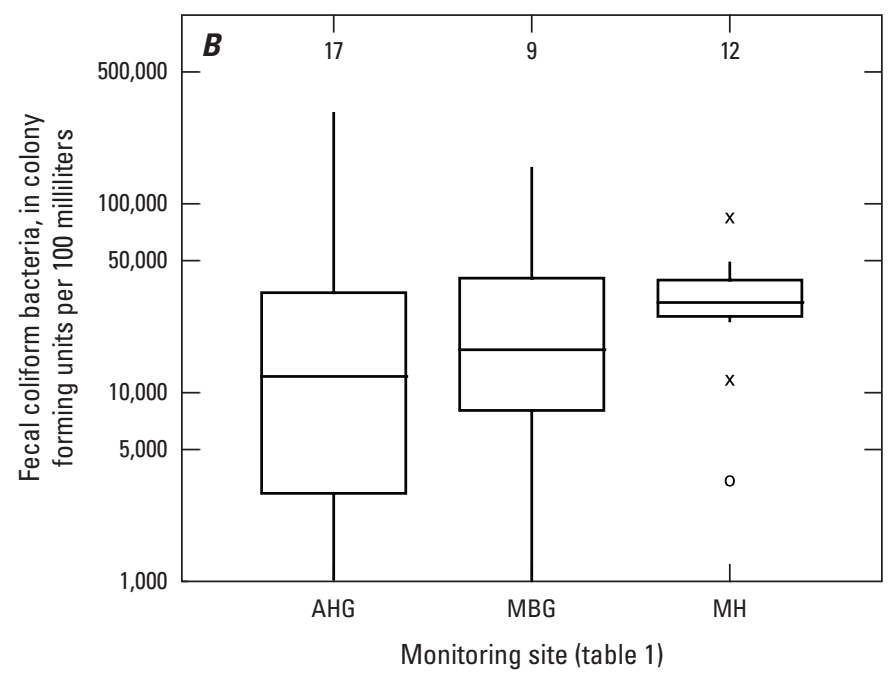

EXPLANATION

12 Number of values

Data value less than or equal to 1.5 times the interquartile range outside the quartile

75th percentile

\begin{tabular}{l|l} 
Median & Interquartile range
\end{tabular}

25th percentile -

Outlier data value greater than 3 times the interquartile range outside the quartile

Outlier data value less than or equal to 3 and more than 1.5 times the interquartile range outside the quartile

Figure 8. Event-mean concentrations for the Arrowhead and Meade-Hawthorne drainage basins, 2008-12. A, total suspended solids; $B$, fecal coliform bacteria; and $C$, Escherichia coli. 

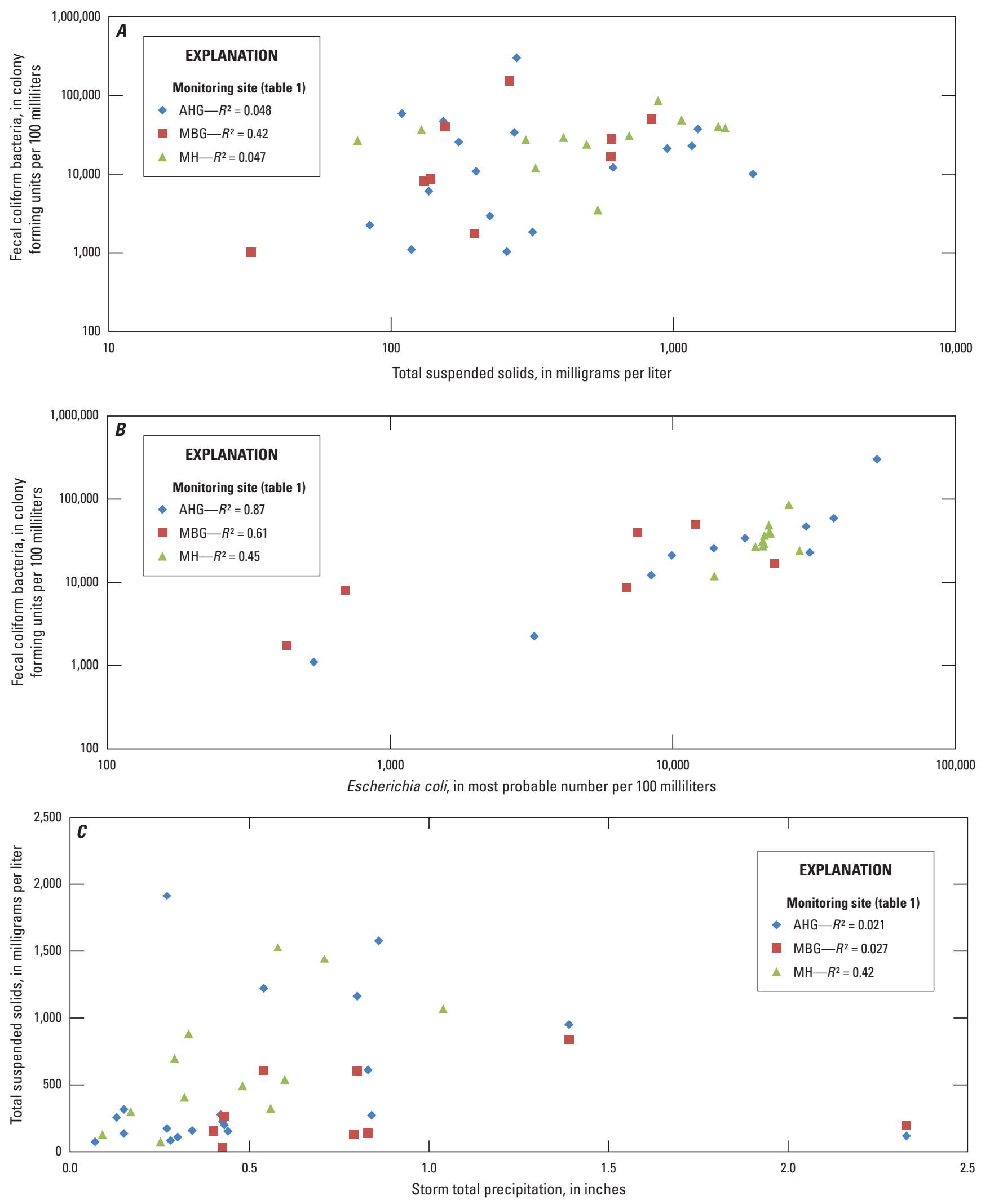

Figure 9. Relations between event-mean concentrations in the Arrowhead and Meade-Hawthorne drainage basins, 2008-12. $A$, total suspended solids and fecal coliform bacteria; $B$, Escherichia coli and fecal coliform bacteria; and $C$, storm total precipitation and total suspended solids. 


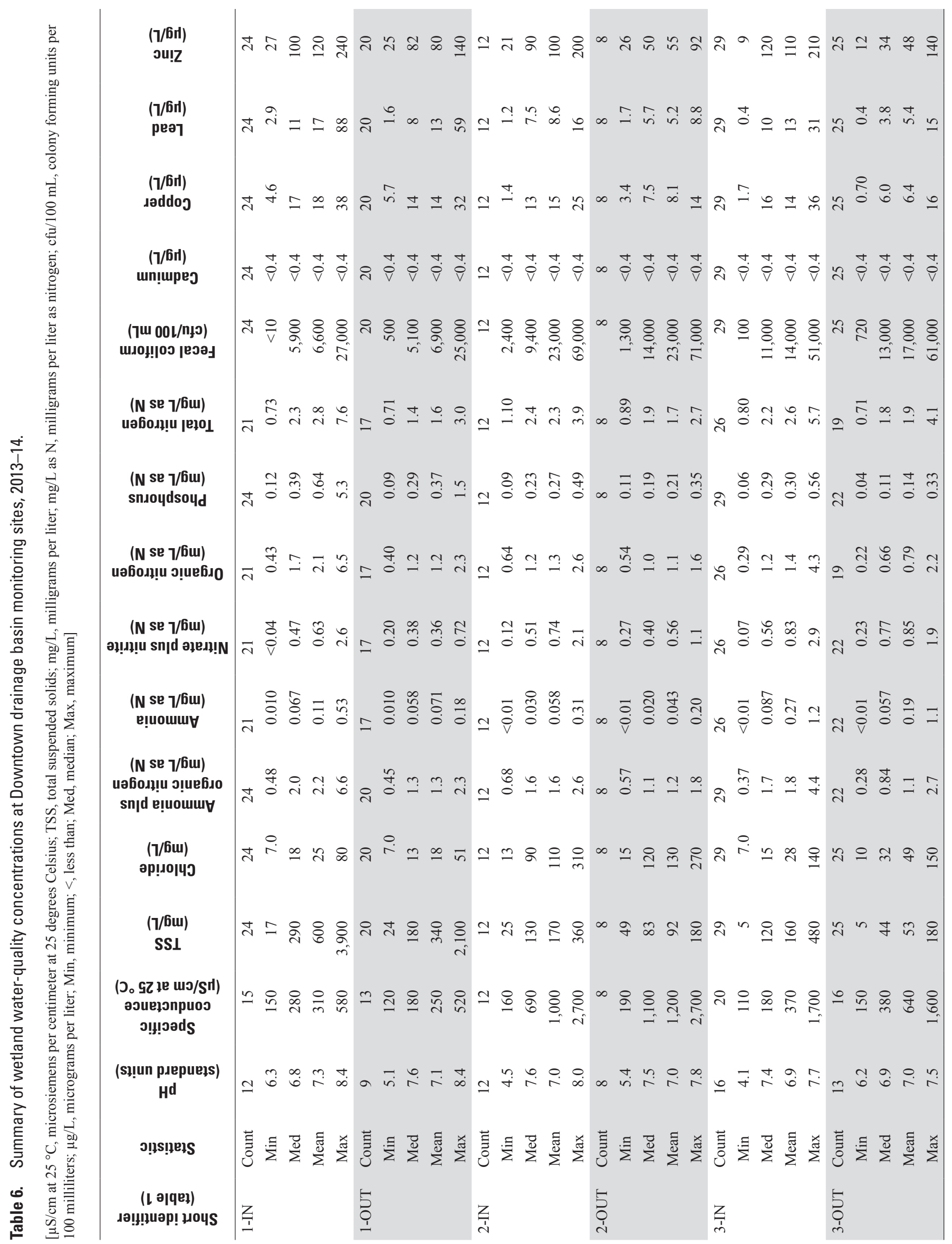



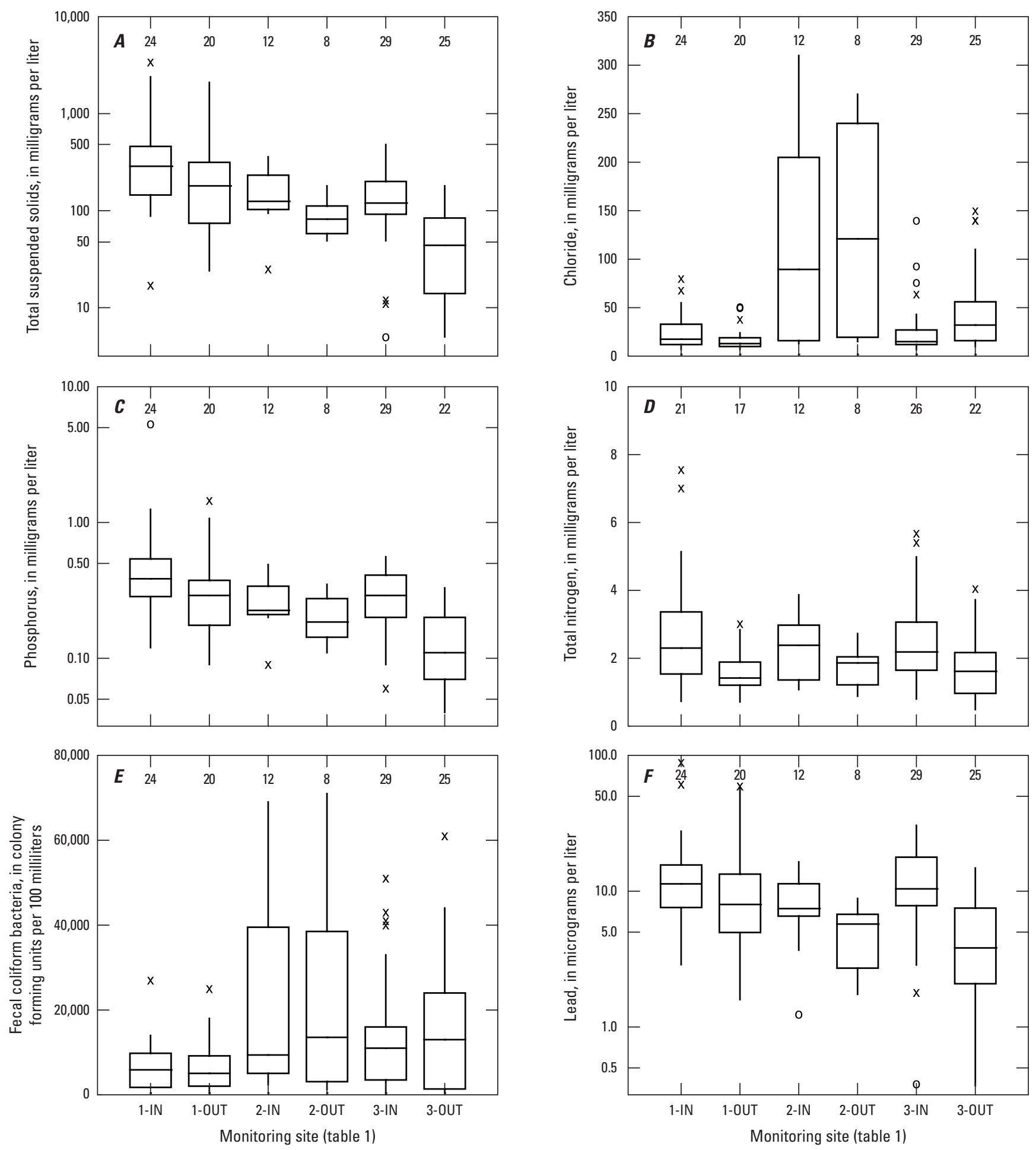

EXPLANATION

Figure 10. Water-quality concentrations at Downtown drainage basin sites, 2013-14. A, total suspended solids; $B$, chloride; $C$, phosphorus; $D$, total nitrogen; $E$, fecal coliform bacteria; and $F$, lead.

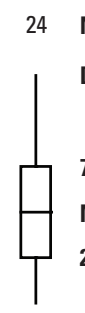

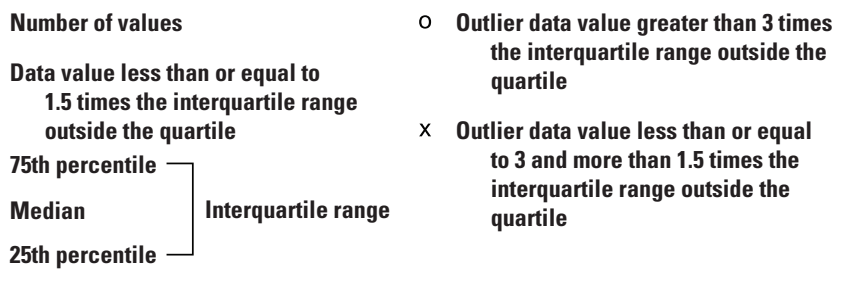


relevant standards, with the exception of lead concentrations that approached or exceeded the $15 \mu \mathrm{g} / \mathrm{L}$ standard in some samples. Comparisons of stormwater runoff concentrations to these drinking-water standards are provided only for reference because the stormwater is not regulated as a direct source of domestic water supply.

Stormwater quality conditions from the Downtown drainage basin outfalls were similar to or better than those observed in the Arrowhead and Meade-Hawthorne drainage basins. Median TSS concentrations at the wetland inlet sites for the 1st, 2nd, and 3rd Street outfalls (sites 1-IN, 2-IN, and 3-IN, respectively) ranged from 120 to $290 \mathrm{mg} / \mathrm{L}$ (table 6), which are similar to the EMC of $200 \mathrm{mg} / \mathrm{L}$ at the Arrowhead outfall (site MBG, table 5) and about one-half of the EMC of $520 \mathrm{mg} / \mathrm{L}$ from the Meade-Hawthorne outfall (site MH). Concentrations of fecal coliform bacteria were consistently lower at the wetland inlet sites for the Downtown drainage basin outfalls, with median values ranging from 5,900 to $11,000 \mathrm{cfu} / 100 \mathrm{~mL}$, compared to median values of $17,000 \mathrm{cfu} / 100 \mathrm{~mL}$ at site $\mathrm{MBG}$ in the Arrowhead drainage basin and of 30,000 cfu/ $100 \mathrm{~mL}$ at site MH in the MeadeHawthorne drainage basin, respectively.

\section{Stormwater Pollutant Reductions}

A comparison of inflow and outflow water-quality concentrations allows for characterization of pollutant reductions at the 1st, 2nd, and 3rd Street wetlands (table 7). The number of events considered at each wetland in table 7 varies because only events deemed to have representative sample coverage at both inflow and outflow sites were included in this analysis. An example set of storm-event data used to estimate reductions is shown in figure 11. For this storm event (September 23, 2013), samples were collected during the rising, peak, and falling hydrograph limbs (fig. 11A), TSS concentrations reduced from the inflow to the outflow (fig. 11B), and fecal coliform bacteria concentrations were greater at the outflow (fig. $11 C$ ). For each event considered in table 7, mean inflow and outflow sample concentrations ( $\bar{C}_{i n}$ and $\bar{C}_{\text {out }}$, respectively) were used to estimate a pollutant reduction in concentration (in percent):

$$
\text { Pollutant reduction }=\left[\left(\bar{C}_{i n}-\bar{C}_{\text {out }}\right) / \bar{C}_{i n}\right] * 100
$$

The means of these storm-specific reductions is used as representative values to assess the performance of the treatment structures in terms of pollutant removal. For comparison, table 2.1 in the "Rapid City Stormwater Quality Manual" (City of Rapid City, 2009) lists expected pollutant removal ranges reported in literature for stormwater BMPs, and the associated ranges for a constructed wetland channel are shown in table 7 . Reductions estimated during this study met or exceeded the expected range for all pollutants listed in the "Rapid City Stormwater Quality Manual."

Certain water-quality constituents were consistently reduced during most events, whereas other constituents were unchanged or even increased in concentration from inflow to outflow. The constituents associated with TSS showed the most efficacy for removal in the wetland channels. Mean reductions in TSS and lead concentrations were greater than 40 percent for all three wetland channels (table 7). Total nitrogen, phosphorus, copper, and zinc concentrations also were reduced by at least 20 percent at all three wetlands. Fecal coliform bacteria concentrations were reduced by about 21 and 36 percent at the 1st and 2nd Street wetlands, respectively, but indicated a mean of about zero percent reduction at the 3rd Street wetland channel. Other studies on stormwater quality from retention ponds and constructed wetlands have noted similar cases of bacteria that were reintroduced into the effluent of these BMPs by turbulent flow causing resuspension or by accumulation through lack of maintenance (Struck and others, 2008; Fisher, 2011). Similarly, the mean reductions in nitrate plus nitrite concentrations were 37 and 33 percent at the 1st and 2nd Street wetlands, respectively, but the mean reduction at the 3rd Street wetland was only about 1 percent. In contrast to the 1st and 2nd Street wetlands, the 3rd Street wetland maintains a permanent pool, which may explain the differences in removal characteristics for certain water-quality constituents. Total storage volume (retention plus detention) has an effect on pollutant reductions, as shown in figure 12 for the 1st, 2nd, and 3rd Street wetlands in the Downtown drainage basin. Pollutant reductions of TSS, phosphorus, and ammonia were greatest in the 3rd Street wetland (fig. 12), which has the greatest total wetland storage volume. Fecal coliform bacteria reduction showed an inverse relation, because the greatest reduction was at the 2 nd Street wetland (smallest total volume). Total storage volume can be directly compared among these wetland BMPs because the flow magnitude in each wetland BMP is similar (same size diversion culvert and flow divider structure). Chloride concentrations typically increased from inflow to outflow at the 2nd and 3rd Street wetland channels (table 6), likely indicating mobilization of salts deposited during prior events. A probable explanation of this phenomenon is the use of road deicers (containing chloride) during the winter months, which wash into the outfalls during snowmelt events and accumulate in the wetlands. Snowmelt events following deicer applications were not sampled during this study. 


\section{Water-Quality Characteristics of Stormwater Runoff in Rapid City, South Dakota, 2008-14}

Table 7. Mean pollutant reductions, in percent, for the 1st, 2nd, and 3rd Street wetland channels in the Downtown drainage basin, 2013-14.

[TSS, total suspended solids; --, not available]

\begin{tabular}{|c|c|c|c|c|c|c|c|c|c|c|c|c|c|}
\hline 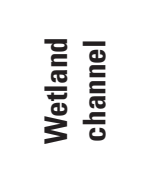 & 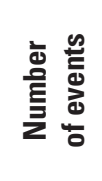 & $\stackrel{\mathscr{L}}{\mathscr{L}}$ & $\frac{\text { 을 }}{\text { 음 }}$ & 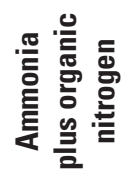 & 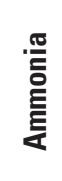 & 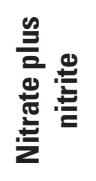 & 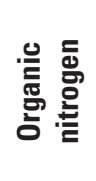 & $\begin{array}{l}\text { 론 } \\
\frac{}{\overline{0}} \\
\frac{0}{0} \\
\frac{0}{\alpha}\end{array}$ & 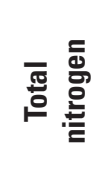 & 焉 豆 竞 & $\frac{\grave{\Xi}}{\frac{0}{0}}$ & 胥 & $\stackrel{\text { 主 }}{ }$ \\
\hline 1st Street & 7 & 50 & 26 & 34 & 33 & 37 & 35 & 40 & 38 & 21 & 23 & 41 & 32 \\
\hline 2nd Street & 4 & 42 & $1-35$ & 23 & 29 & 33 & 18 & 22 & 20 & 36 & 49 & 42 & 48 \\
\hline \multicolumn{2}{|c|}{$\begin{array}{l}\text { Expected probable } \\
\text { range }^{2}\end{array}$} & $30-50$ & -- & -- & -- & -- & -- & $20-40$ & $10-30$ & -- & -- & $20-40$ & $20-40$ \\
\hline
\end{tabular}

${ }^{1}$ Negative values indicate mean pollutant concentration was greater at the outflow than inflow.

${ }^{2}$ From table 2.1 in "Rapid City Stormwater Quality Manual” (City of Rapid City, 2009).
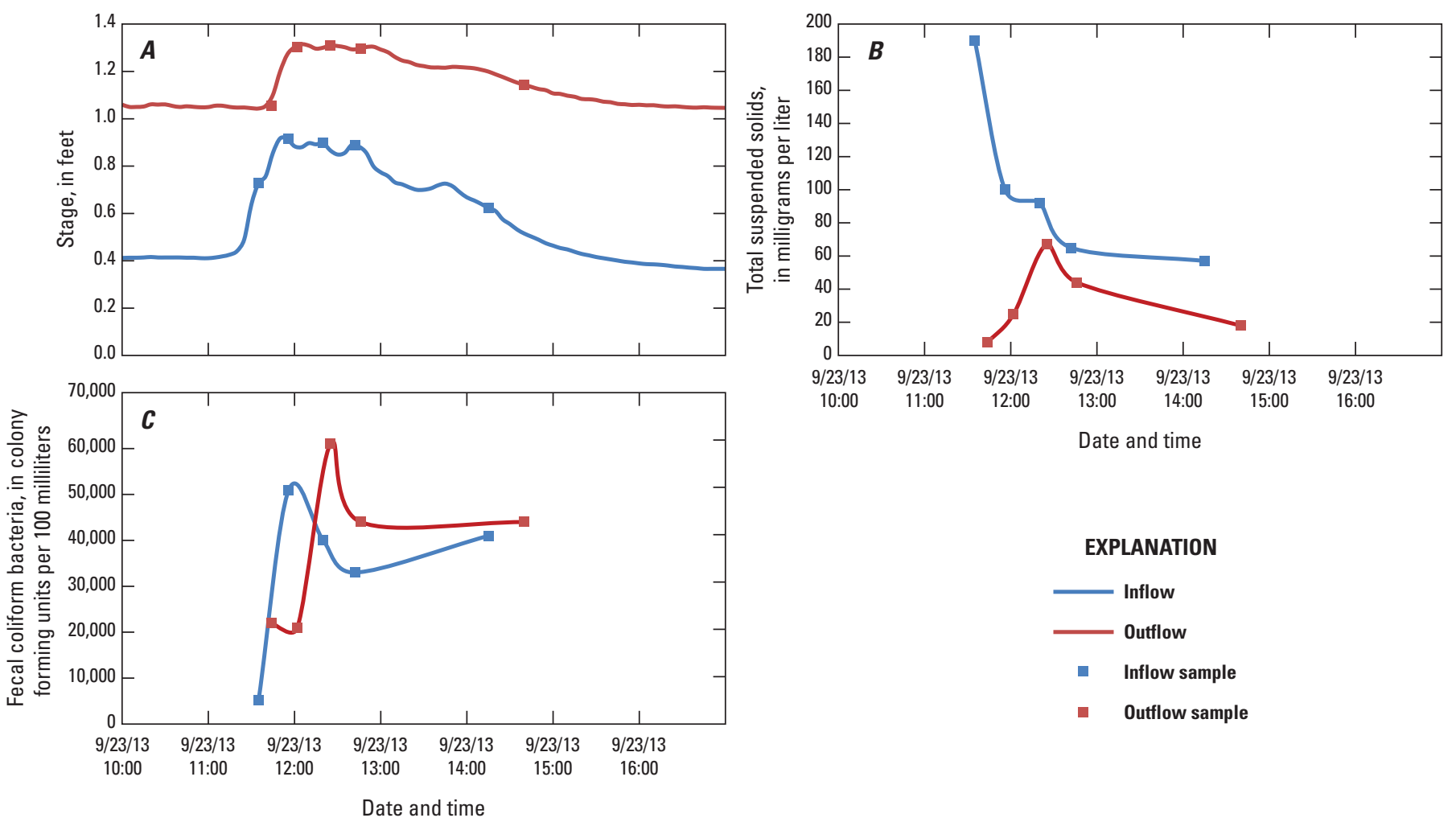

Figure 11. Inflow and outflow data for 3rd Street wetland channel in the Downtown drainage basin during runoff event on September 23 , 2013. $A$, stage hydrograph and sample times; $B$, total suspended solids concentration; and $C$, fecal coliform bacteria concentration. 


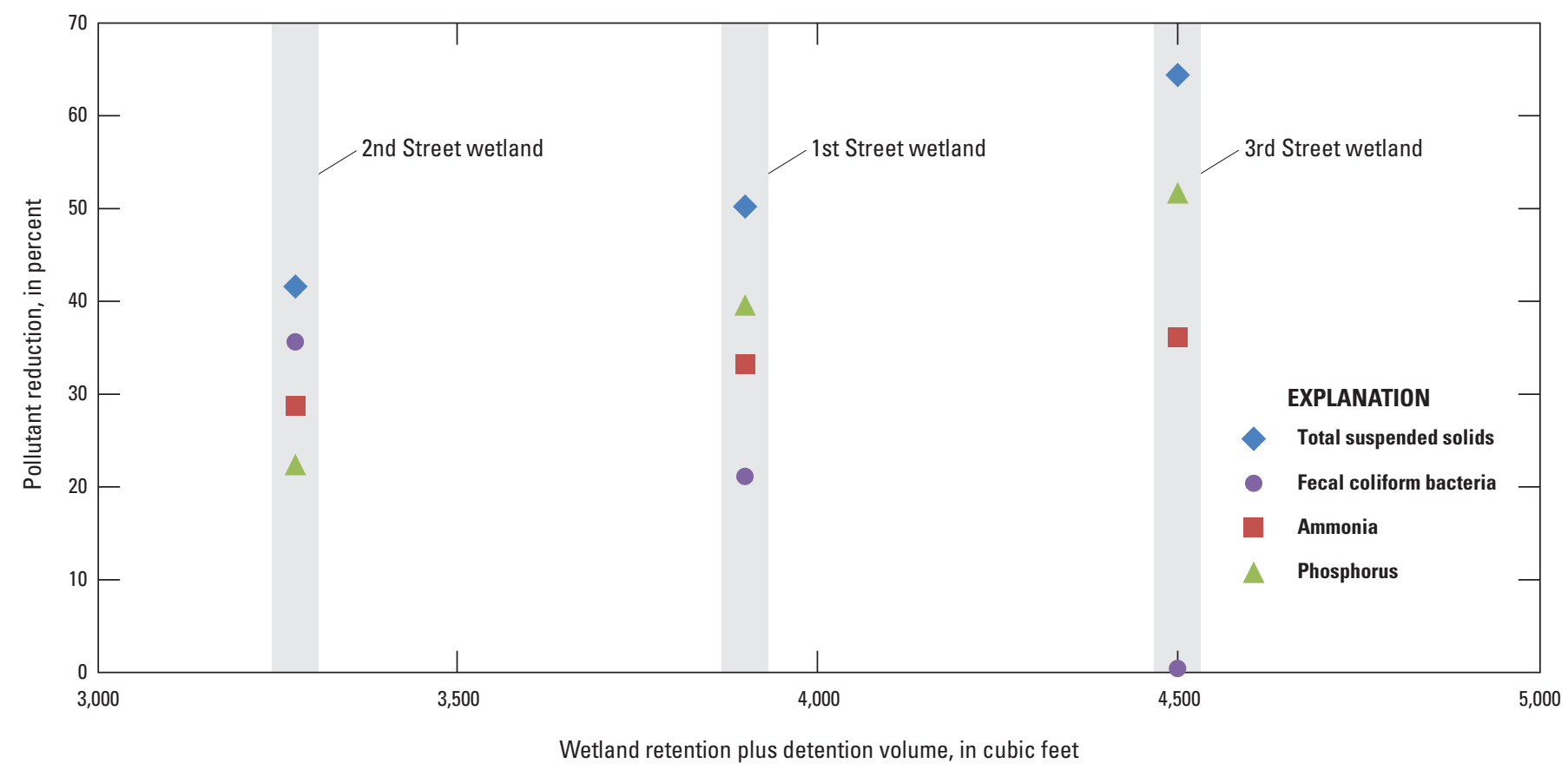

Figure 12. Relation between wetland total volume and pollutant reductions for total suspended solids, ammonia, phosphorus, and fecal coliform bacteria for the wetland channels in the Downtown drainage basin, 2013-14.

\section{Summary}

The water quality of Rapid Creek is important because the reach that flows through Rapid City, South Dakota, is a valuable spawning area for a self-sustaining trout fishery, actively used for recreation, and a seasonal municipal water supply for the City of Rapid City. Control of sediment generated by construction sites and from urban land use within Rapid City is necessary for Rapid Creek to maintain a waterquality condition that satisfies its beneficial uses. To characterize the composition of stormwater runoff and to better understand the effects of best-management practices on the quality of stormwater runoff, the U.S. Geological Survey (USGS) completed a study in cooperation with the City of Rapid City. The objectives of this study were to characterize the current (2008-14) composition of urban stormwater runoff in selected drainage networks within the City of Rapid City, and evaluate the pollutant reductions of wetland channels implemented as a best-management practice.

Stormwater data were collected in three drainage basins within Rapid City: the Arrowhead, Meade-Hawthorne, and Downtown drainage basins. Land-use characteristics differ among the three basins. The mean percentage of impervious area for the Meade-Hawthorne drainage basin is 38 percent, compared to 9.6 percent in the Arrowhead drainage basin. The predominantly open vegetated channels in the Arrowhead drainage basin contrast to the concrete channels and conduits in the Meade-Hawthorne drainage basin. The Downtown drainage basin consists of several small drainage networks originating from the highly urbanized areas of downtown Rapid City, with impervious areas greater than 90 percent. The areas monitored in the Downtown drainage basin as part of this study include the 1st, 2nd, and 3rd Street outfalls and their wetland channel best-management practices. Waterquality concentration information includes total suspended solids (TSS) and bacteria concentrations at the Arrowhead and Meade-Hawthorne drainage basins, and in addition, chloride, nutrients, and metals at the Downtown drainage basin.

At the two monitoring sites in the Arrowhead drainage basin (an upstream site and a downstream site at the basin outlet into Rapid Creek) and the one monitoring site in the Meade-Hawthorne drainage basin (at the basin outlet to Rapid Creek), a total of 357 water-quality samples were collected during 2008-12 and analyzed for TSS, fecal coliform, and Escherichia coli. All event-mean concentrations (EMCs) exceeded the TSS and bacteria beneficial-use criteria for Rapid Creek, typically by 1-2 orders of magnitude. Comparing TSS concentrations between the Arrowhead and Meade-Hawthorne drainage basins, median EMCs were more than two times greater at the Meade-Hawthorne outlet (520 milligrams per liter) than at the Arrowhead outlet (200 milligrams per liter). Median EMCs for fecal coliform bacteria also were greater at the Meade-Hawthorne outlet (30,000 colony forming units per 100 milliliters) than at the Arrowhead outlet (17,000 colony forming units per 100 milliliters). Median EMCs for TSS were similar between the upstream and downstream sites in the 
Arrowhead drainage basin because no instream BMPs have been designed to reduce pollutant concentrations between these sites. At the Arrowhead and Meade-Hawthorne sites, the correlation of EMCs for TSS and bacteria was poor.

During 2013-14, 118 water-quality samples were collected at the 1st, 2nd, and 3rd Street outfalls of the Downtown drainage basin from six sites. A comparison of concentrations in stormwater runoff samples to relevant standards indicated that stormwater runoff from the Downtown drainage basin exceeded criteria for fecal coliform bacteria and TSS, but concentrations generally were below standards for nutrients and metals. Stormwater quality conditions from the Downtown drainage basin outfalls were similar to or better than those observed in the Arrowhead and Meade-Hawthorne drainage basins. Three wetland channels located at the outlet of the Downtown drainage basin were evaluated for their pollutant reduction capability. Certain water-quality constituents were uniformly reduced between the wetland inflow and outflow during most events, whereas other constituents were unchanged or even increased in concentration from inflow to outflow. The constituents associated with suspended sediments showed the most efficacy for removal in the wetland channels. Mean reductions in TSS and lead concentrations were greater than 40 percent for all three wetland channels. Total nitrogen, phosphorus, copper, and zinc concentrations also were reduced by at least 20 percent at all three wetlands. Fecal coliform bacteria concentrations typically were reduced by about 21 and 36 percent at the 1st and 2nd Street wetlands, respectively, but indicated a mean of zero percent reduction at the 3rd Street wetland channel. Total storage volume (retention plus detention) affects pollutant reductions because TSS, phosphorus, and ammonia reductions were greatest in the wetland with the greatest volume. Chloride concentrations typically increased from inflow to outflow at the 2nd and 3rd Street wetland channels.

\section{References Cited}

American Public Health Association, 2015, Standard methods for the examination of water and wastewater (online edition): Washington, D.C., American Public Health Association, American Water Works Association, and Water Environment Federation, accessed March 18, 2015, at http://www.standardmethods.org/store/.

Baker, K.K., 2010, Monitoring stormwater quality in the Arrowhead drainage basin, Rapid City, South Dakota, 2008-2009: Rapid City, South Dakota School of Mines and Technology M.S. Thesis, 109 p.

City of Rapid City, 2009, City of Rapid City stormwater quality manual: accessed May 1, 2013, at http://www.rcgov.org/ Public-Works/stormwater-homepage.html.
Driscoll, D.G., Bunkers, M.J., Carter, J.M., Stamm, J.F., and Williamson, J.E., 2010, Thunderstorms and flooding of August 17, 2007, with a context provided by a history of other large storm and flood events in the Black Hills area of South Dakota: U.S. Geological Survey Scientific Investigations Report 2010-5187, 139 p. [Also available at http:// pubs.usgs.gov/sir/2010/5187/.]

Fisher, E., 2011, Monitoring and performance of best management practices for stormwater runoff in Rapid City, SD: Rapid City, South Dakota School of Mines and Technology M.S. Thesis, $52 \mathrm{p}$.

Fishman, M.J., ed., 1993, Methods of analysis by the U.S. Geological Survey National Water Quality Laboratory-Determination of inorganic and organic constituents in water and fluvial sediments: U.S. Geological Survey Open-File Report 93-125, 217 p.

Fry, J., Xian, G., Jin, S., Dewitz, J., Homer, C., Yang, L., Barnes, C., Herold, N., and Wickham, J., 2011, Completion of the 2006 national land cover database for the conterminous United States: Photogrammetric Engineering and Remote Sensing, v. 77, no. 8, p. 858-864.

Haan, C.T., 1977, Statistical methods in hydrology: Ames, Iowa, Iowa State University Press, p. 176-178.

Helsel, D.R. and Hirsch, R.M., 2002, Statistical methods in water resources: U.S. Geological Survey Techniques of Water-Resources Investigations, book 4, chapter A3, 522 p.

Hoffman, G.L., Fishman, M.J., and Garbarino, J.R., 1996, Methods of analysis by the U.S. Geological Survey National Water Quality Laboratory-In-bottle acid digestion of whole-water samples: U.S. Geological Survey Open-File Report 96-225, 28 p.

Kenner, S., and Craft, L., 1997, Prioritization of storm water impact on water quality for development of a best management practice demonstration project: Rapid City, South Dakota, School of Mines and Technology, $171 \mathrm{p}$.

Krantz, E.L., 2002, Urban runoff water-quality impacts to brown trout (Salmo trutta) in Rapid Creek, Rapid City, South Dakota: Rapid City, South Dakota School of Mines and Technology M.S. Thesis, $115 \mathrm{p}$.

Lawrence, S.J., 2012, Escherichia coli bacteria density in relation to turbidity, streamflow characteristics, and season in the Chattahoochee River near Atlanta, Georgia, October 2000 through September 2008-Description, statistical analysis, and predictive modeling: U.S. Geological Survey Scientific Investigations Report 2012-5037, 81 p. [Also available at http://pubs.usgs.gov/sir/2012/5037/.] 
Lopes, T.J., Fossum, K.D., Phillips, J.V., and Monical, J.E., 1994, Statistical summary of selected physical, chemical, and microbial characteristics and estimates of constituent loads in urban stormwater, Maricopa County, Arizona: U.S. Geological Survey Water-Resources Investigations Report 94-4240, 62 p.

National Oceanic and Atmospheric Administration, 2014, Data tools-1981-2010 normals: National Climatic Data Center, accessed October 28, 2014, at http://www.ncdc.noaa.gov/ cdo-web/datatools/normals.

National Oceanic and Atmospheric Administration, 2015, Daily Summaries Station Details: National Climatic Data Center, accessed April 27, 2015, at http://www. ncdc.noaa.gov/cdo-web/datasets/GHCND/stations/ GHCND:USC00396948/detail.

Pfaff, J.D., 1993, Determination of inorganic anions by ion chromatography: Environmental Monitoring Systems Laboratory, U.S. Environmental Protection Agency, accessed October 16, 2014, at http://water.epa.gov/scitech/ methods/cwa/bioindicators/upload/2007_07_10_methods method_300_0.pdf.

Prann, R.A., 2013, Modeling the effect of urbanization on two watersheds in Rapid City, SD using SWMM: Rapid City, South Dakota School of Mines and Technology M.S. Thesis, $121 \mathrm{p}$.

Pirner, S., and Harms, L.L., 1978, Rapid City combats the effects of urban runoff on surface water: Water and Sewage Works, v. 125, no. 2, p. 48-53.

Rasmussen, T.J., and Schmidt, H.C., 2009, Stormwater runoff-What it is and why it is important in Johnson County, Kansas: U.S. Geological Survey Fact Sheet 2009-3103, 2 p., accessed April 17, 2015, at http://pubs.usgs.gov/ fs $/ 2009 / 3103 /$.

Rasmussen, P.P., and Ziegler, A.C., 2003, Comparison and continuous estimates of fecal coliform and Escherichia coli bacteria in selected Kansas streams, May 1999 Through April 2002: U.S. Geological Survey Water-Resources Investigations Report 03-4056, 87 p.

Sauer, V.B., and Turnipseed, D.P., 2010, Stage measurement at gaging stations: U.S. Geological Survey Techniques and Methods, book 3, chap. A7, 45 p. [Also available at http:// pubs.usgs.gov/tm/tm3-a7/.]

Schiferl, K., 2011, Sediment as source of fecal coliform in stormwater runoff in the Arrowhead and Meade-Hawthorne drainage basins: Rapid City, South Dakota School of Mines and Technology M.S. Thesis, 70 p.
South Dakota Department of Environment and Natural Resources, 2010, Surface water quality standards: accessed June 22, 2010, at http://denr.sd.gov/des/sw/swqstandards. aspx.

South Dakota Department of Environment and Natural Resources, 2014, The 2014 South Dakota integrated report for surface water quality assessment: accessed October 15, 2014, at http://denr.sd.gov/des/sw/IntegratedReports.aspx.

South Dakota Department of Environment and Natural Resources, 2015, Nonpoint source pollution total maximum daily loads (TMDLs): accessed February 11, 2015, at http://denr.sd.gov/dfta/wp/tmdl.aspx.

Struck, S.D., Selvakumar, A., and Borst, M., 2008, Prediction of effluent quality from retention ponds and constructed wetlands for managing bacterial stressors in stormwater runoff: Journal of Irrigation and Drainage Engineering, v. 134 , no. 5 , p. $567-578$.

Timme, P.J., 1995, National Water Quality Laboratory, 1995 services catalog: U.S. Geological Survey Open-File Report 95-352, $92 \mathrm{p}$.

Turnipseed, D.P., and Sauer, V.B., 2010, Discharge measurements at gaging stations: U.S. Geological Survey Techniques and Methods, book 3, chap. A8, 87 p. [Also available at http://pubs.usgs.gov/tm/tm3-a8/.]

U.S. Environmental Protection Agency, 1983, Results of the nationwide urban runoff program-executive summary: U.S. Environmental Protection Agency Water Planning Division, $24 \mathrm{p}$.

U.S. Environmental Protection Agency, 2003, After the storm-A citizen's guide to understanding stormwater: U.S. Environmental Protection Agency EPA 833-B-03-002, 5 p., accessed April 17, 2015, at http://water.epa.gov/action/ weatherchannel/index.cfm.

U.S. Environmental Protection Agency, 2010, Stormwater phase II final rule fact sheet series: accessed March 4, 2015, at http://water.epa.gov/polwaste/npdes/stormwater/Stormwater-Phase-II-Final-Rule-Fact-Sheet-Series.cfm.

U.S. Environmental Protection Agency, 2014, National primary drinking water regulations: accessed December 17, 2014, at http://water.epa.gov/drink/contaminants/index.cfm.

U.S. Geological Survey, variously dated, National field manual for the collection of water-quality data: U.S. Geological Survey Techniques of Water-Resources Investigations, book 9, chaps. A1-A9 [variously paged], accessed March 18, 2015, at http://pubs.water.usgs.gov/twri9A. 
U.S. Geological Survey, 2010, Collection, quality assurance, and presentation of precipitation data: Office of Surface Water Technical Memorandum No. 2006.01, revised February 2010, accessed April 22, 2015, at http://water.usgs.gov/ $\mathrm{admin} / \mathrm{memo} / \mathrm{SW} / \mathrm{OSW}$ 2006-01_Revised_02122010.pdf.

U.S. Geological Survey, 2015, USGS surface-water data for South Dakota: U.S. Geological Survey National Water Information System, accessed April 20, 2015, at http:// waterdata.usgs.gov/sd/nwis/sw/.

Wisconsin Department of Natural Resources, 2009, Beach health: accessed August 25, 2009, at http://www.wibeaches. us/traverse/f?p=BEACH:ABOUT:2686495812053843. 


\section{Appendix 1}

A complete listing of the water-quality data for stormwater runoff samples collected from the Arrowhead, Meade-Hawthorne, and Downtown drainage basins are presented in the Microsoft ${ }^{\mathbb{R}}$ Excel file at http://pubs.usgs.gov/sir/2015/5069/downloads/sir2015-5069_appendix1.xlsx. The Microsoft ${ }^{\circledR}$ Excel file contains the following four worksheets:

1. "Info" worksheet describes contents of the Microsoft ${ }^{\circledR}$ Excel file and abbreviations,

2. "Arrowhead" worksheet contains discharge data and water-quality sample results from the Arrowhead drainage basin,

3. "MeadeHawthorne" worksheet contains discharge data and water-quality sample results from the Meade-Hawthorne drainage basin, and

4. "Downtown" worksheet contains water-quality sample results from the Downtown drainage basin. 
Publishing support provided by: Rolla Publishing Service Center

For more information concerning this publication, contact: Director, USGS South Dakota Water Science Center 1608 Mountain View Road

Rapid City, South Dakota 57702

(605) 394-3200

Or visit the South Dakota Water Science Center Web site at: http://sd.water.usgs.gov/ 

